\title{
A Stratified Random Sampling Plan for an Irrigation Customer Telephone Survey
}

May 1986

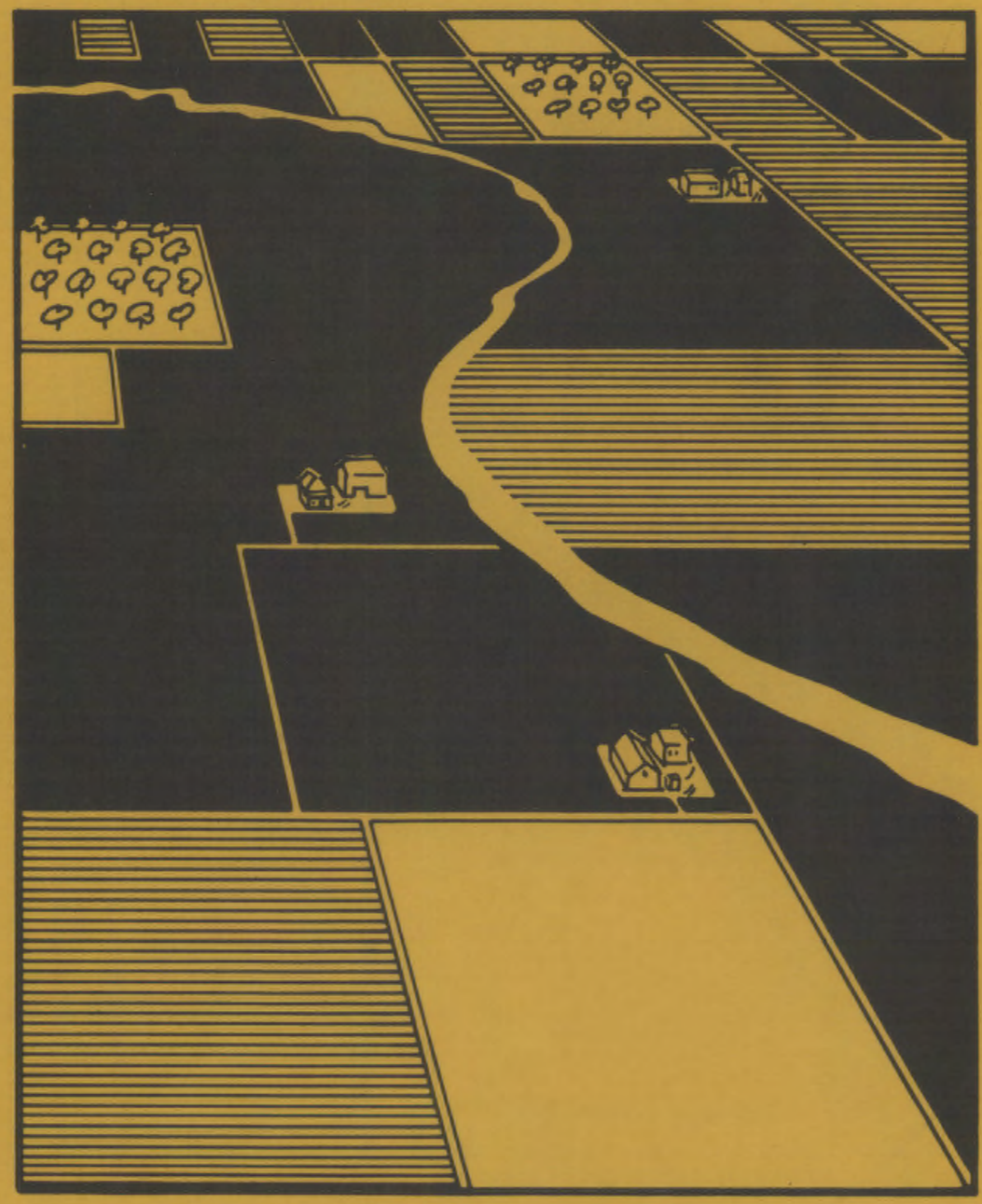

Prepared for the Bonneville Power Administration under a Related Services Agreement with the U.S. Department of Energy Contract DE-AC06-76RLO 1830

Pacific Northwest Laboratory Operated for the U.S. Department of Energy by Battelle Memorial Institute 


\title{
DISCLAIMER
}

This report was prepared as an account of work sponsored by an agency of the United States Government. Neither the United States Government nor any agency thereof, nor any of their employees, makes any warranty, express or implied, or assumes any legal liability or responsibility for the accuracy, completeness, or usefulness of any information, apparatus, product, or process disclosed, or represents that its use would not infringe privately owned rights. Reference herein to any specific commercial product, process, or service by trade name, trademark, manufacturer, or otherwise, does not necessarily constitute or imply its endorsement, recommendation, or favoring by the United States Government or any agency thereof. The views and opinions of authors expressed herein do not necessarily state or reflect those of the United States Government or any agency thereof.

\author{
PACIFIC NORTHWEST LABORATORY \\ operated by \\ BATTELLE \\ for the \\ UNITED STATES DEPARTMENT OF ENERGY \\ under Contract DE-AC06-76RLO 1830
}

\begin{tabular}{|c|c|}
\hline \multicolumn{2}{|c|}{ Printed in the United States of America } \\
\hline \multicolumn{2}{|c|}{ Available from } \\
\hline \multicolumn{2}{|c|}{ National Technical Information Service } \\
\hline \multicolumn{2}{|c|}{ United States Department of Commerce } \\
\hline \multirow{2}{*}{\multicolumn{2}{|c|}{$\begin{array}{l}5285 \text { Port Royal Road } \\
\text { Springfield, Virginia } 22161\end{array}$}} \\
\hline & \\
\hline \multirow{2}{*}{\multicolumn{2}{|c|}{$\begin{array}{l}\text { NTIS Price Codes } \\
\text { Microfiche A01 }\end{array}$}} \\
\hline & \\
\hline \multicolumn{2}{|c|}{ Printed Copy } \\
\hline & \\
\hline Pages & Codes \\
\hline 001-025 & $\mathrm{A} 02$ \\
\hline $026-050$ & $\mathrm{~A} 03$ \\
\hline 051-075 & $A 06$ \\
\hline 076-100 & A05 \\
\hline $101-125$ & $A 06$ \\
\hline $126-150$ & A07 \\
\hline $151-175$ & $A 06$ \\
\hline $176-200$ & A09 \\
\hline $201-225$ & A010 \\
\hline $226-250$ & A011 \\
\hline $251-275$ & A012 \\
\hline $276-300$ & A013 \\
\hline
\end{tabular}


PNL-5866

UC $-95 \mathrm{C}$

A STRATIFIED RANDOM SAMPLING PLAN FOR AN IRRIGATION CUSTOMER TELEPHONE SURVEY

J. W. Johnston

L. J. Davis

B. J. Harrer, Project Manager

May 1986

Prepared for the Bonneville Power Administration under a Related Services Agreement with

the U.S. Department of Energy

Contract DE-ACO6-76RLO 1830

Pacific Northwest Laboratory

Richland, Washington 99352 
. 
SUMMARY

This report describes the procedures used to design and select a sample for a telephone survey of individuals who use electricity in irrigating agricultural cropland in the Pacific Northwest. (a) The survey is sponsored by the Bonneville Power Administration (BPA) and is intended to gather information on the irrigated agricultural sector that will be useful for conservation assessment, load forecasting, rate design, and other regional power planning activities.

The sample is a stratified two-stage sample. Fight strata were defined to correspond to geographic agricultural production areas (APAs). In these eight strata, the irrigated farms in the Pacific Northwest are grouped into areas with similar cropping and climatic characteristics. The first-stage primary sampling units (PSUS) are utilities with an irrigation load in a geographic strata. Utilities serving customers in two or more APAs were correspondingly partitioned into two or more PSUs. At the second stage, irrigation accounts from the selected utility's billing records were sampled.

Distributional analysis of the Mh billed by each PSU showed that a cut point at 30,000 MWh was appropriate for separating the PSUs into high and low Mh groups. About 91 percent of the total regional irrigation load was used by high group utilities with irrigation loads exceeding 30,000 MWh. A11 29 PSUs in the high group were selected for the sample.

Another 23 PSUs in the low MWh group were randomly selected from among all remaining PSUs with irrigation loads. The final PSU sample for the survey included 40 utilities partitioned into 52 PSUs that accounted for 97 percent of 1980 Pacific Northwest regional irrigation load. The sample represents every geographic area in the region where electricity is used for irrigation and includes both public and private (investor-owned) utilities.

(a) For purposes of this study, the Pacific Northwest is defined as Washington, Oregon, Idaho, Montana (west of the Continental Divide) and very small parts of Wyoming, Utah, Nevada and California where the service areas of utilities supplied by BPA power cross into these states. 
Approximately 1700 telephone responses were allocated to the selected PSUs based on the relative sizes of their 1984 irrigation loads. As a result of this process, 1500 responses were allocated to the high group PSUs and 200 responses were allocated to the low group. Allocations to individual PSUs ranged from 6 to 200 .

Elementary sampling unit (ESU) customers were selected for the sample by first partitioning the PSU's irrigation loads into six customer usage strata (II-strata). Based on an analysis of the distribution of irrigation loads, the highest usage stratum (high U-stratum) was usually defined as any irrigation customer using in excess of $500 \mathrm{MWh}$ in a year. The other five usage strata each accounted for 20 percent of the utility's remaining irrigation load after the high I-stratum load had been subtracted. All customers in the high $\mathrm{U}$-stratum were selected for the sample. Equal numbers of customers from each of the five remaining IJ-strata were also selected until the number of responses allocated to the PSI was reached.

In some cases, utilities were unable to provide MWh consumption data by customer because of the format of their billing record system. In such cases, sample selection was based on the distribution of irrigation meter $k$ hh consumption, with consideration for the potential for multiple meters per customer incorporated in the sampling calculations. Cross-checking the sampled meters for duplicate customers was also necessary when metered data were used in sampling.

The stratified random sampling methods used in this study will provide better precision in estimating the parameters of interest to BPA in the irrigation sector than would simple random sampling methods. The process of developing and implementing stratified random sampling methods for 40 utilities with different billing record formats was time-consuming and difficult. However, the validity of the survey results will be significantly enhanced because these methods were used. 


\section{CONTENTS}

SUMMARY

GLOSSARY

ix

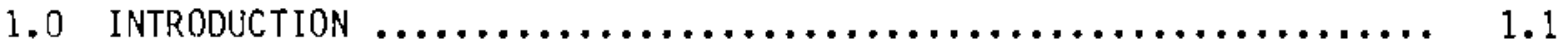

2.0 RESIULTS AND CONCLUSIONS $\ldots \ldots \ldots \ldots \ldots \ldots \ldots \ldots \ldots \ldots \ldots \ldots \ldots \ldots \ldots \ldots \ldots \ldots$

3.0 SAMPLE SELECTION AND RESPONSE ALLOCATION AT

THE UTILITY LEVEL $\ldots \ldots \ldots \ldots \ldots \ldots \ldots \ldots \ldots \ldots \ldots \ldots \ldots \ldots \ldots \ldots \ldots \ldots \ldots \ldots \ldots$

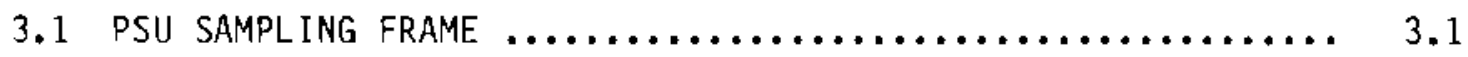

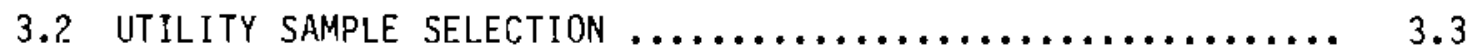

3.3 INITIAL ALLOCATION OF CUSTOMER INTERVIEWS

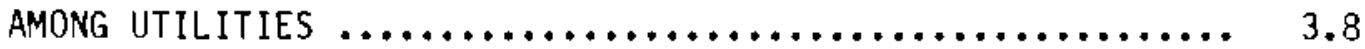

3.3.1 High and Low Mh Group Interview Allocations........ 3.8

3.3.2 Individual Utility Interview Allocations ......... 3.10

4.0 GENERAL SAMPLE SPECIFICATION AND SELECTION AT THE ESU LEVEL $\ldots . .4 .1$

4.1 ESU SAMPLE SPECIFICATION $\ldots \ldots \ldots \ldots \ldots \ldots \ldots \ldots \ldots \ldots \ldots \ldots \ldots \ldots \ldots \ldots \ldots \ldots \ldots$

4.2 GENERAL DESCRIPTION OF SAMPLING METHODS FOR

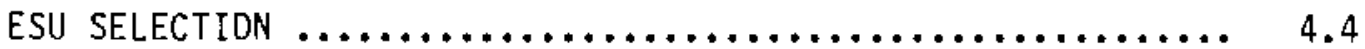

5.0 UTILITY SPECIFIC SAMPLING METHODS $\ldots \ldots \ldots \ldots \ldots \ldots \ldots \ldots \ldots \ldots \ldots$

5.1 SAMPLING METHOD ALTERNATIVES $\ldots \ldots \ldots \ldots \ldots \ldots \ldots \ldots \ldots \ldots \ldots . . \ldots \ldots$

5.1.1 Method 1 - Sampling from an Ordered Customer List ....................... 5.1

5.1.2 Method 2 - Sampling from a Customer List Not Sorted by kwh Usage $\ldots \ldots \ldots \ldots \ldots \ldots \ldots \ldots \ldots \ldots \ldots, 5.2$

5.1.3 Method 3 - Sampling from an Drdered Meter Listing ....................... 5.3

5.1.4 Method 4 - Sampling from a Metered List Not Sorted by kwh Usage ........................ 5.3

5.1.5 Method 5 - Utility Sampling from Specified

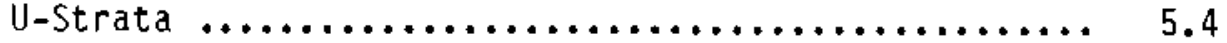


5.2 SAMPLING METHODS USED ON IRRIGATION SIJRVEY UTILITIES $\ldots \ldots \ldots \quad 5.4$

5.2.1 Customer Consumption Data Provided by the Utility ............................... 5.5

5.2.2 Metered Consumption Data Provided by the Utility .... 5.5

5.2.3 Utilities That Performed the Sampling Procedure According to Specified U-Strata .................. 5.5

5.3 RESPONSE ALLOCATION ADJUSTMENTS $\ldots \ldots \ldots \ldots \ldots \ldots \ldots \ldots \ldots . \ldots . \ldots . \ldots$

5.4 PROBLEMS OCCASIONED BY SAMPLING BILLING RECORDS $\ldots \ldots \ldots \ldots \ldots . . \ldots .11$

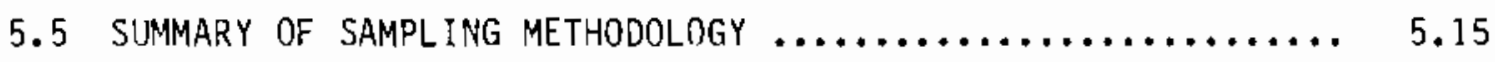

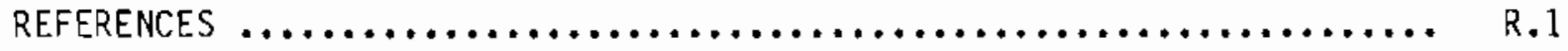

APPENDIX A - SAMPLING WORK SHEETS $\ldots \ldots \ldots \ldots \ldots \ldots \ldots \ldots \ldots \ldots \ldots \ldots \ldots \ldots \ldots$

APPENDIX B - ALPHABETICAL LISTING OF UTILITIES INCLUDED IN SAMPLE ... B. 1 


\section{FIGURES}

3.1 Pacific Northwest Agricultural Production Areas ............. 3.1

TABLES

3.1 Geographic Strata Designations Defined For This Study ........ 3.2

3.2 Characteristics of Irrigation Survey Sampling Frame, High MWh Group ................................. 3.3

3.3 Characteristics of Irrigation Survey Sampling Frame, Low Wh Group ................................... 3.4

3.4 Utilities With Irrigation Loads Exceeding 30,000 Mth Selected

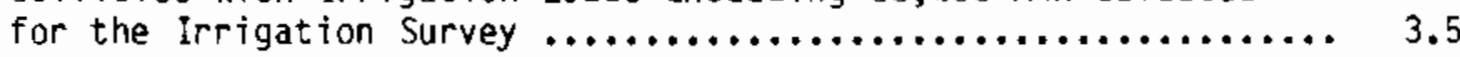

3.5 Utilities in Low Mh Group Initially Selected for Sample ...... 3.7

3.6 Utilities Selected for Irrigation Survey Sample ............ 3.9

3.7 Initial Allocated Successful Telephone Responses for High

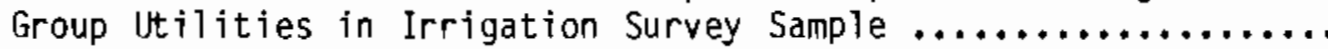

3.8 Allocated Successful Telephone Responses for Low Group Utilities in Irrigation Survey Sample ............... 3.13

4.1 Definition of Upper Limits in Mh for Low Usage Strata in Each

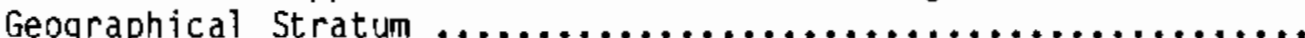

4.2 Example of Sample Allocation for Customer Data ............. 4.8

4.3 Average Meters per Customer ........................ 4.10

4.4 Example of Sample Allocation for Meter Data ............... 4.12

5.1 Utilities Providing Customer Irrigation Consumption Data ..... 5.6

5.2 Utilities Providing Metered Irrigation Consumption Data ....... 5.7

5.3 Utilities Which Performed Sampting Procedures According to Specified U-Strata Provided by PNL .................... 5.7

5.4 Final Allocated Successful Telephone Responses for High Group Primary Sampling Units in Irrigation Survey Sample ........... 5.9

5.5 Final Allocated Successful Telephone Responses for Low Group Primary Sampling Units in Irrigation Survey Sample 
5.6 Sample Data on Nonirrigated Farm Loads Contained in Irrigation Billing Records ................................... 5.12

5.7 Initial Response Al Iocations for Utilities Requiring Customer Permission for Name Release and Names Actually Received ........ 5.14

A.1 Worksheet for Sampling From Customer kWh Load Data Using

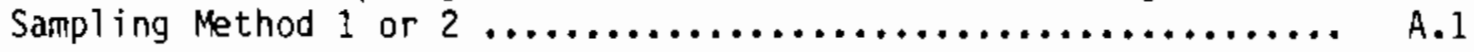

A.2 Worksheet for Sampling From Customer kWh Load Data Using Sampling Method 3 or 4

A.3 
GLOSSARY

DEFINITIONS

UNIVERSE (to be sampled) AIl "irrigated farms" located in the Pacific Northwest region. [Operationally: all "irrigation accounts" listed in utility records]. For purposes of this study, the Pacific Northwest region is defined as the states of Washington, Oregon, Idaho, Montana (west of the Continental Divide), and very Small parts of Wyoming, Utah, Nevada and Cal ifornia where the service areas of public utilities supplied by $B P A$ power cross into these states.

\section{FLIGIBLE RESPONDENTS}

FLEMENTARY SAMPLING UNITS (ESU)

PRIMARY SAMPLING

UNITS (PSU)

AGR ICULTURAL PRODUCTION AREA (APA)

SAMPLING PROPORTIONATE TO SIZE
Farm managers or irrigation managers for farms.

Irrigation accounts 1 isted in Pacific Northwest utility records; about 55,200 in 1982 count of irrigation customers or meters. Many utilities do not have the capability to efficiently aggregate multiple meter charges billed to the same irrigation operation. That is, they cannot convenientiy produce a "customer" listing that contains the total annual usage (kWh) per customer, since multiple bills (one for each meter), are sent to the "customer." Thus, depending on the utility, an ESU may be either an irrigation customer or an irrigation meter. Adjustments in sampling procedures were necessary when utilities were only able to provide consumption data by meter.

Partitioned utilities that include those farms in a utility's service area that are located in a specific agricultural production area (APA). By this definition, the 78 utilities with irrigation loads produce 103 PSU.

A geographical partitioning of the BPA service area into eight areas that have similar cropping and $\mathrm{Cl} i-$ matic patterns. The eight APAs will be treated as geographic strata in the sampling.

Here, size is defined as Mh delivered to all irrigation customers by a PSU and, at the customer (ESU) level, by the MWh billed to the farm or meter. 


\subsection{INTRODUCTION}

The purpose of this report is to specify a sample design for a survey to determine the irrigation system characteristics, irrigation practices, and attitudes regarding them, of operators of irrigated farms in the Pacific Northwest region. The Bonneville Power Administration (BPA) requested that Pacific Northwest Laboratory (PNL) design, manage and analyze the results of this survey as part of an effort to gather information for conservation planning, load forecasting and other purposes within BPA. One important product of the survey will be an extensive computerized data base on the characteristics of irrigation operations in the Pacific Northwest for use by BPA conservation planners and others. Energy use (MWh) for irrigation and number of irrigation accounts at the utility level will be used in defining the sampling frame for the survey.

This report is divided into five chapters. Chapter 2.0 summarizes the results of the sample design and selection process. The third chapter describes the procedures that were used to select utilities for inclusion in the irrigation survey sample and to allocate the 1700 total required responses among the sampled utilities. Chapter 4.0 presents the general methodology developed for selecting irrigation customers from within the various utilities for inclusion in the irrigation survey sample. The final chapter of the report describes the sampling procedures that were implemented at each utility included in the survey sample. 
$=$ 


\subsection{RESIULS AND CONCLUSIONS}

In designing the sample for the irrigation customer telephone survey, BPA and PNL project staff identified several requirements:

1. Financial resources for the survey required that the number of customer telephone responses to the survey be 1 imited to approximateiy 1700 and the number of utilities in the sample to approximately 50

2. The utilities and irrigation customers selected for the sample should represent a high proportion of Pacific Northwest irrigation electrical demand

3. The sample should be as representative as possible (given requirement 2) of the total population of irrigators in the Pacific Northwest.

The sample design described in this report fulfilis these requirements. It is a stratified two-stage sample that includes both large and small utilities (in terms of irrigation loads) and large and small irrigation customers from within utility service areas. It covers all of the geographic areas in the Pacific Northwest where electricity is used for irrigation and includes both public and private utilities.

The eight geographic strata (G-strata) used in partitioning Pacific Northwest utilities with irrigation loads into primary sampling units (PSUs) range from western Montana to the Oregon/Washington coast, and represent every geographic area in the region where electricity is used for irrigation. The 29 high group PSUs that were selected with probability one for inclusion in the sample (based upon a 1980 irrigation load within a G-strata in excess of $30,000 \mathrm{MWh}$ ) represented 91 percent of 1980 regional irrigation load. The 23 low MWh group PSUs that were selected for the sample based on the relative size of their irrigation load within a G-strata (from among PSUs with irrigation loads less than $30,000 \mathrm{MWh}$ ) raised the percentage of total regional 1980 irrigation load contained in the survey PSU sample to approximately

97 percent. 
The 52 PSIIs selected for the sample equate to 40 different utilities because some of the selected utilities span multiple APAs. All of the private (investor-owned) utilities in the Pacific Northwest with irrigation loads were included in the survey, except Puget Sound Power and Light. A total of 35 public utilities were included in the sample.

Initial survey response allocations to PSUs based on the relative sizes of their irrigation loads resulted in Idaho Power Company receiving the largest allocation (500 responses) among all utilities. Allocating almost 30 percent of the survey responses to one utility seemed to be a clear over-allocation of resources that would not allow for other utilities to be adequately represented in the study. Thus, Idaho Power's final response allocation was reduced to 200. This allocation was still the largest among all selected utilities, but it allowed for an additional 300 responses to be available for allocating to other PSU utilities. Grant County Public Utility District received the largest response allocation among public utilities at 175 .

Private utilities received 35 percent of the final total response allocation (627 responses) and public utilities received 65 percent (1182 responses). As stated previously, private and public high MWh group PSUs were initially allocated 1500 total responses while low MWh group PSUs were initially allocated 200 responses. However, where possible, the sampling procedure required a minimum of two responses per MWh usage strata (U-strata) within each utility. This led to a final total response allocation of 1809 .

Seven utilities representing approximately 13 percent of 1984 regional irrigation load required that customers' permission be received either through a signed consent form or a telephone call before the customers' names could be released for inclusion in the survey sample. This requirement resulted in unforeseen reductions in sample sizes for these utilities. Irrigation customers from these utilities will be under-represented in the survey compared to the representation that would have been obtained from response levels initially allocated to them. However, the significance of the problem introduced by the permission requirements cannot be assessed until response levels to the survey are known, billing records for survey respondents are obtained, and statisitical weights for the survey responses are developed. 
Selection of ESUs (irrigation accounts) for the sample was based on the stratification of billed electric loads within the selected utilities into six usage strata (U-strata). Based on an analysis of load (MWh) distribution by account from 19 purposely selected PSUs representing all eight APAs, it was decided that all irrigation accounts with annual loads in excess of 500 MWh should be included in the survey sample. This cut point defined the highest U-strata for 38 of the 40 utilities in the sample. It allowed for a significant proportion of the selected utilities' total loads to be included in the sample while also allowing for adequate representation of lower Wh consumption customers.

The five lower U-strata were defined based on 20 percent increments in the utilities' load that remained after the load of all high stratum customers was subtracted out. An equal number of customers were then selected for the survey sample from each of the five lower U-strata. For the majority of the irrigation load contained in the survey sample, it was possible to define utilityspecific cut points, but in some cases, it was necessary to use the "representative" cut points calculated from the purposely selected PSUs for each G-strata because of a lack of utility-specific MWh distribution data.

The Tack of individual customer consumption data for some utilities required the use of meter data for approximately 30 percent of the irrigation load contained in the study sample. This introduced some statistical problems into the stratified sample selection process. These problems were dealt with by using sampling procedures that incorporated data on the number of meters per customer in the sampling steps. After the survey is taken and customer consumption data are available from all utilities, survey participants for which onty metered data were available can be more accurately classified into their correct usage strata.

SUMMARY

The sampling methods used in this study will provide much more precise estimates for the regional irrigation sector than would result from using a simple random sample of the same size. Selecting high usage PSUs and ESUs with certainty, while selecting low usage PSUs and ESUs proportional to size, will 
provide for a much higher percentage of $P N W$ regional irrigation load to be included in the survey. In addition, at each stage of sampling, high usage units are effectively censused, so they do not contribute to sampling error at their aggregation level. An example analysis was performed to characterize the potential improvement in estimation precision resulting from the use of the sampling methods described in this report. In this example, the relative standard deviation of an estimate of total MWh used for irrigation in Grant County PUD was reduced from 18.9 percent in a purely random sample to 2.6 percent for the sampling plan described in this study. 


\subsection{SAMPLE SELECTION AND RESPONSE ALLOCATION AT THE UTILITY (PSU) LEVEL}

This chapter describes the procedures used to select utilities for the irrigation survey sample in such a way that a high level of Pacific Northwest regional irrigation load would be represented in the sample while also achieving a high level of geograhic and usage diversity within the sample. It also presents the procedures used to allocate approximately 1700 successful telephone responses requested by BPA to the utilities in the sample.

\subsection{PSU SAMPLING FRAME}

Previous studies (Harrer, Lezburg and Wilfert 1985) on the irrigation sector in the Pacific Northwest have separated the region into the 11 agriculturat production areas (APAs) illustrated in Figure 3.1. These APAs are designed to broadly group irrigation customers into areas that have similar climates and cropping patterns. In this study, BPA desired that particular emphasis be given to APAs 2, 3, 6 and 10 in constructing a sample framework for the survey because these APAs comprise the major portion (over 80 percent) of

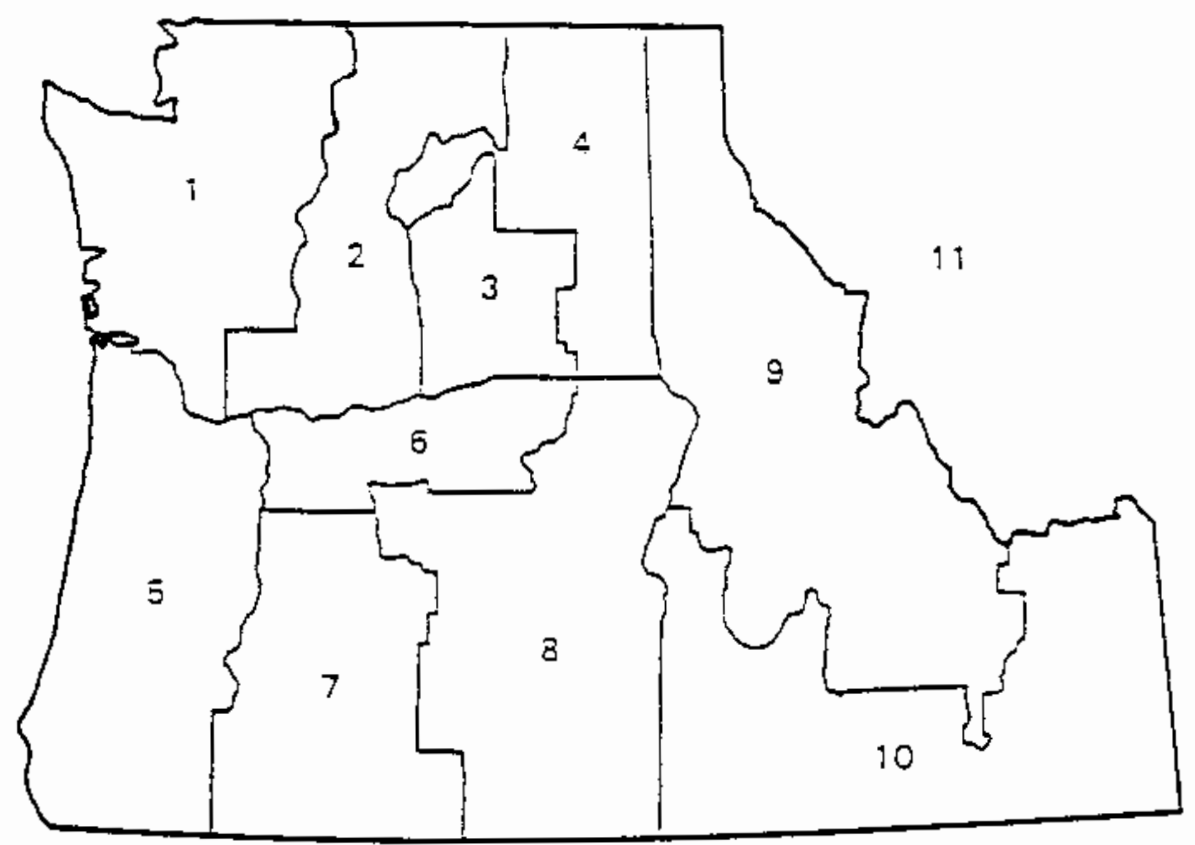

FIGURE 3.1. Pacific Northwest Agricultural Production Areas (APAs) 
the regional irrigation load. The remaining seven "lower load" APAs were conbined into four geographic strata. This process resulted in the geographic strata (G-strata) designations for this study listed in Table 3.1 .

Data on the MWh delivered to irrigation accounts by utilities in $1980(a)$ provided the basis for defining the sampling plan. These data were augmented by the 1982 data on number of irrigation accounts. (b) These data showed that the combined load of utilities with individual loads greater than 30,000 MWh comprised about 90 percent of total regional irrigation load. Thus, a load of 30,000 MWh was designated as a cut point for sampling, with all utilities with loads greater than $30,000 \mathrm{MWh}$ in a G-strata classified into a high Mwh group and all utilities with loads less than this amount classified into a low Nh group.

TABLE 3.1. Geographic Strata Designations Defined For This Study

\begin{tabular}{ccc}
$\begin{array}{c}\text { Strata Designation } \\
\text { For This Study }\end{array}$ & $\begin{array}{c}\text { Previous APA Designation } \\
\text { (From Figure 1) }\end{array}$ & $\begin{array}{c}\text { Emphasis Level } \\
\text { Requested For Sampling }\end{array}$ \\
\cline { 2 - 3 } 2 & $\begin{array}{c}10 \text { - Southern Idaho } \\
3\end{array}$ & High \\
4 & 2 - Columbia Basin & High \\
5 & 7 - North Central Oregon & High \\
& 8 - Southern Oregon \\
6 & 4 - Eastern Washington \\
7 & 9 - Northern Idaho & Low \\
& 11 - Western Montana & Low \\
8 & 5 - Western Washington & Low \\
& 5 - Western Oregon & Low
\end{tabular}

(a) Unpublished data developed by Northwest Economic Associates and supplied by Fred Gordon, Conservation Planning, Bonneville Power Administration.

(b) Inpublished data supplied by Cam Downing, Power Forecasting, Bonneville Power Administration. 
Some characteristics of the primary sampling unit (PSU) utilities in the high and low MWh groups are listed in Tables 3.2 and 3.3. The PSU defined by Idaho Power Company serving farms in Stratum 1 (APA 10) delivered about 4.5 times as many MWh as the next largest PSU (IJtah Power and Light, also in Stratum 1), so a special stratum was created for it.

\subsection{UTILITY (PSU) SAMPLE SELECTION}

According to the sampling strategy developed for use in this project, all utilities in the high MWh group are included with a probability of one. The utilities selected on this basis are shown in Table 3.4 .

\section{TABLE 3.2. Characteristics of Irrigation Survey Sampling Frame,
High MWh Group}

\begin{tabular}{|c|c|c|c|c|c|c|}
\hline G-Stratum Number & 0 & I. HIE & $\begin{array}{c}\text { H EMPHASIS } \\
2 \\
\end{array}$ & 3 & 4 & Total \\
\hline APA Number & 10 & 10 & 3 & 6 & 2 & \\
\hline APA Name & $\begin{array}{l}\text { tdaho Power } \\
\text { Co. }\end{array}$ & $\begin{array}{l}\text { Southern } \\
\text { Idaho }\end{array}$ & $\begin{array}{l}\text { Columbia } \\
\text { Basin }\end{array}$ & $\begin{array}{l}\text { No. Central } \\
\text { Oregon }\end{array}$ & $\begin{array}{l}\text { Yakima } \\
\text { valley }\end{array}$ & \\
\hline No. of PSU Utilitites & 1 & 2 & 8 & 3 & 4 & 18 \\
\hline No, of ESU Accounts & 10,102 & 1,875 & 9,471 & 3,061 & 5,349 & 29,858 \\
\hline 1980 MWh Irrigation Load & $1,414,611$ & 453,222 & $1,051,4681$ & 425,138 & 217,615 & $3,562,054$ \\
\hline \% of Total PNW Load & 30.9 & 9.9 & 23.0 & 9.3 & 4.8 & 77.9 \\
\hline of High Group Load ${ }^{(b)}$ & -- & 16.6 & 38.4 & 15.5 & 8.0 & 78.5 \\
\hline No, of Respondents & 200 & 215 & 502 & 203 & 102 & 1,222 \\
\hline
\end{tabular}

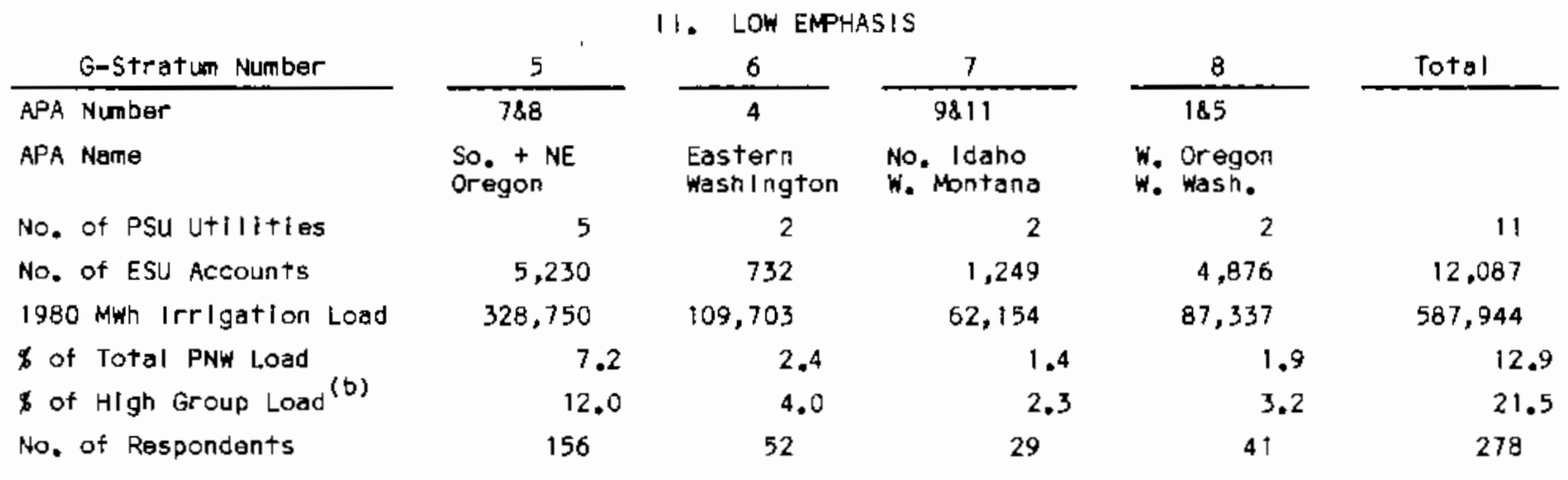

(a) High Mhh group is defined as any utility withIn an APA that had an irrigation load of 30,000 Mwh in 1980.

(b) Represents percentage of total 1980 Pacific Northwest regional load comprised by all high group utilities in each geographie stratum, excluding Idaho Power Co. 
TABLE 3.3. Characteristics of Irrigation Survey Sampling Frame,
Low MWh Group

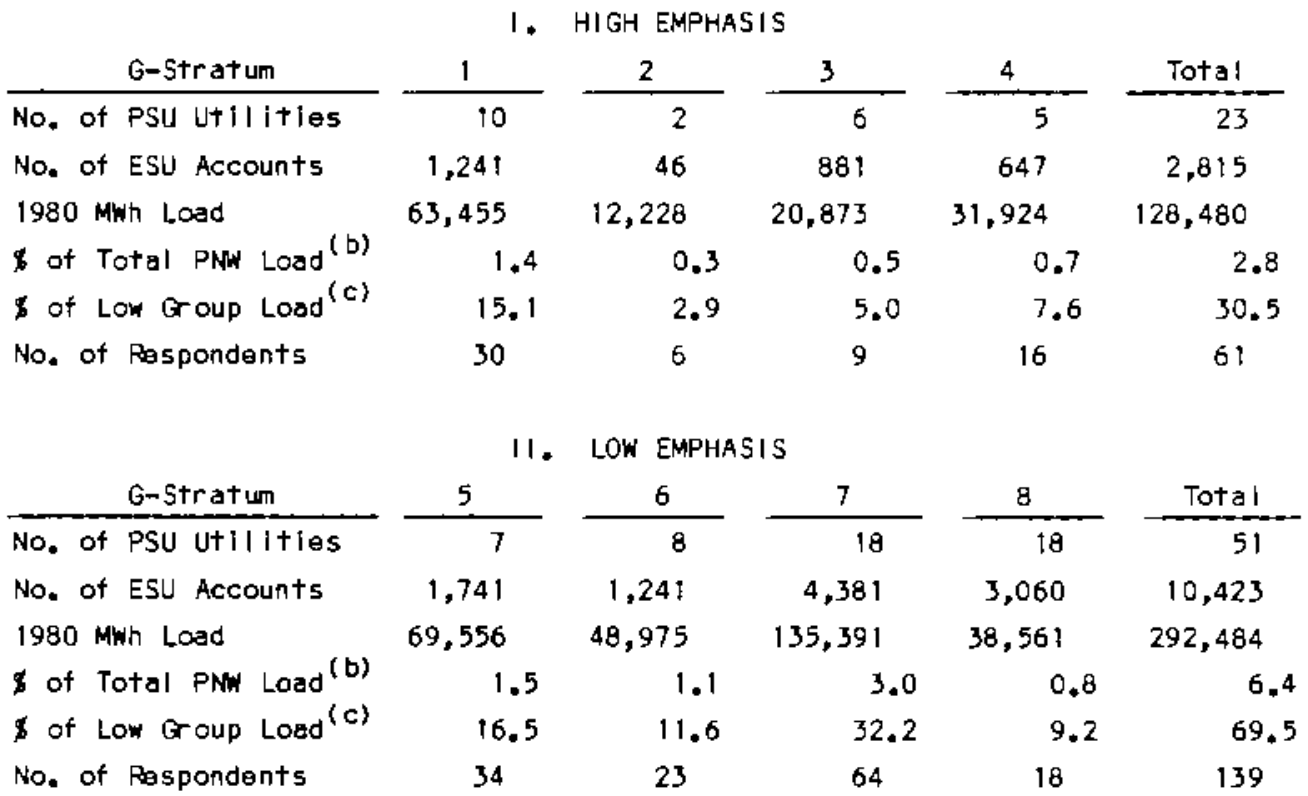

(a) Low MWh group is defined as any utllity withln an APA that reported an Irrigation ioad of less than 30,000 Mwh in 1980 .

(b) Represents percentage of total 1980 Paclific Northwest regional irrigation load comprised by all low group utilities in each geographic stratum.

(c) Represents percentage of total 1980 low group reglonal Irrigation load comprised by all low group utilities in each geograhic stratum.

Initial specifications were that "about 50 " utilities in total should be contacted. Since 29 PSUs were sampled in the high group, about 20 utilities need to be sampled from the low MWh group to meet this requirement. It is advisable to have at least two utilities selected in each of the G-strata. The first step was to allocate among G-strata the approximately 20 utilities to be sampled based on "\% of Low MWh Group" figures in Table 3.3, with the additional constraint of at least two utilities in each stratum. This gives the following allocation, requiring 23 PSUs.

$\begin{array}{lllllllll}\text { G-Stratum } & 1 & 2 & 3 & 4 & 5 & 6 & 7 & 8 \\ \text { No. of PSUs } & 3 & 2 & 2 & 2 & 3 & 2 & 7 & 2\end{array}$


TABLE 3.4. Utilities With Irrigation Loads Exceeding 30,000 MWh Selected for the Irrigation Survey

\begin{tabular}{|c|c|c|}
\hline Utility Name & $\begin{array}{l}\text { G-Stratum } \\
\text { Number }\end{array}$ & Agricultural Production Area \\
\hline $\begin{array}{l}\text { Idaho Power Company } \\
\text { Utah Power and Light } \\
\text { Raft River Coop. }\end{array}$ & $\begin{array}{l}0(1)^{(a)} \\
1 \\
1\end{array}$ & $\begin{array}{l}\text { Southern Idaho } \\
\text { Southern Idaho } \\
\text { Southern Idaho }\end{array}$ \\
\hline $\begin{array}{l}\text { Grant County PUD } \\
\text { Big Bend Electric } \\
\text { Benton County PUD } \\
\text { Franklin County PUD } \\
\text { Columbia REA } \\
\text { Pacific Power and Light } \\
\text { Benton REA } \\
\text { Washington Water Power }\end{array}$ & $\begin{array}{l}2 \\
2 \\
2 \\
2 \\
2 \\
2 \\
2 \\
2\end{array}$ & $\begin{array}{l}\text { Columbia Basin } \\
\text { Columbia Basin } \\
\text { Columbia Basin } \\
\text { Columbia Basin } \\
\text { Columbia Basin } \\
\text { Columbia Basin } \\
\text { Columbia Basin } \\
\text { Columbia Basin }\end{array}$ \\
\hline $\begin{array}{l}\text { Umatilla Electric Coop. } \\
\text { Pacific Power and Light } \\
\text { Columbia Basin Coop. }\end{array}$ & $\begin{array}{l}3 \\
3 \\
3\end{array}$ & $\begin{array}{l}\text { North Central Oregon } \\
\text { North Central Oregon } \\
\text { North Central Oregon }\end{array}$ \\
\hline $\begin{array}{l}\text { Pacific Power and Light } \\
\text { Okanogan PUD } \\
\text { Benton REA } \\
\text { Chelan County PUD }\end{array}$ & $\begin{array}{l}4 \\
4 \\
4 \\
4\end{array}$ & $\begin{array}{l}\text { Yakima Valley } \\
\text { Yakima Valley } \\
\text { Yakima Valley } \\
\text { Yakima Valley }\end{array}$ \\
\hline $\begin{array}{l}\text { Pacific Power and Light } \\
\text { Harney Electric Coop. } \\
\text { Idaho Power Co. } \\
\text { Central Elec. Coop. } \\
\text { Midstate Coop. }\end{array}$ & $\begin{array}{l}5 \\
5 \\
5 \\
5 \\
5\end{array}$ & $\begin{array}{l}\text { Southern and N.E. Oregon } \\
\text { Southern and N.E. Oregon } \\
\text { Southern and N.E. Oregon } \\
\text { Southern and N.E. Oregon } \\
\text { Southern and N.E. Oregon }\end{array}$ \\
\hline $\begin{array}{l}\text { Lincoln Coop. (WA) } \\
\text { Washington Water Power }\end{array}$ & $\begin{array}{l}6 \\
6\end{array}$ & $\begin{array}{l}\text { Eastern Washington } \\
\text { Eastern Washington }\end{array}$ \\
\hline $\begin{array}{l}\text { Lost River Coop. } \\
\text { Vigilante Electric Coop. }\end{array}$ & $\begin{array}{l}7 \\
7\end{array}$ & $\begin{array}{l}\text { Northern Idaho - W. Montana } \\
\text { Northern Idaho - W. Montana }\end{array}$ \\
\hline $\begin{array}{l}\text { Pacific Power and Light } \\
\text { Portland General Electric }\end{array}$ & $\begin{array}{l}8 \\
8\end{array}$ & $\begin{array}{l}\text { W. Washington - W. Oregon } \\
\text { W. Washington - W. Oregon }\end{array}$ \\
\hline
\end{tabular}

(a) Idaho Power Company's irrigation Ioad is primarily located in Geographic Stratum 1, but its relative irrigation load is so large that it was assigned its own stratum. 
The required number of low-range PSUs allocated to each G-stratum were then selected with probability proportional to size within the G-stratum. The 2 to 18 PSUs in each stratum were ordered from highest to lowest MWh usage, the: cumulative percentage of the totai Mwh usage within each stratum used by each utility in the stratum was calculated. Then, the required number of sampled PSUs was selected by using computer-generated random numbers between 0 and 100 . The first PSU selected was the one whose cumulative usage percentage included the first selected random number. This process was continued in each G-stratum by skipping random numbers that fell in the range of utilities already selected until the required number of PSUs in each stratum was reached. The utilities initially selected by this method are listed in Table 3.5.

More random numbers were generated than the required number of utilities for each stratum so that alternate utilities would be available if we were unable to get a selected utility to participate in the study. These alternates are also listed in Table 3.5 and were used in the following cases:

1. East End Mutual was substituted for Rural Electric Company in Geographic Stratum 1 because the Board of Directors of Rural Electric Company voted not to participate in the irrigation study, citing a "lack of staff time" as the reason for refusal.

2. At the request of BPA staff, Fall River Electric Cooperative was substituted for South Side Electric Lines in Geographic Stratum 1 because of Fall River's more extensive involvement in BPA-sponsored programs.

3. South Side Electric Lines was substituted for Unity Power and Light in Geographic Stratum 1 because Unity Light and Power was unable to deliver requested sampling data within the time period required to construct the survey sample.

4. C.P. National in Geographic Stratum 5 was dropped from the study because its Oregon operations are now being acquired by Idaho Power and a considerable amount of sensitivity would be associated with any requests for data. Individuals from Umatilla Electric Cooperative 
TABLE 3.5. Utilities in Low MWh Group(a) Initially Selected for Sample

\begin{tabular}{|c|c|c|c|}
\hline Itility & $\begin{array}{c}\text { Goographic } \\
\text { Strata } \\
\end{array}$ & $\begin{array}{l}1980 \mathrm{MW} \\
\text { Hour Load } \\
\end{array}$ & $\begin{array}{l}\text { Selection } \\
\text { Order } \\
\end{array}$ \\
\hline $\begin{array}{l}\text { Fall River Cooperative } \\
\text { South Side Electric Lines } \\
\text { Rural Electric Company } \\
\text { Unity LIght and Power Company } \\
\text { East End Mutual }\end{array}$ & $\begin{array}{l}1 \\
1 \\
\vdots \\
1 \\
1\end{array}$ & $\begin{array}{r}24,559 \\
12,914 \\
10,916 \\
7,001 \\
3,856\end{array}$ & $\begin{array}{l}5^{(c)} \\
3 \\
2 \\
1 \\
4\end{array}$ \\
\hline $\begin{array}{l}\text { RIchland Energy Service } \\
\text { Lincoln Electric Coop. }\end{array}$ & $\begin{array}{l}2 \\
2\end{array}$ & $\begin{array}{l}8,442 \\
3,756\end{array}$ & $\begin{array}{l}2 \\
1\end{array}$ \\
\hline $\begin{array}{l}\text { Wasco Electric Coop. } \\
\text { Hood River Electric Coop. } \\
\text { Korth Wasco PuD } \\
\text { Col umbia Power Coop. }\end{array}$ & $\begin{array}{l}3 \\
3 \\
3 \\
3\end{array}$ & $\begin{array}{l}9,430 \\
1,391 \\
1,257 \\
5,800\end{array}$ & $\begin{array}{l}2(c) \\
4(c) \\
3\end{array}$ \\
\hline $\begin{array}{l}\text { Klickitat County PUD } \\
\text { Nespelem Valley Electric Coop. } \\
\text { Kittitas County PUD } \\
\text { Puget Sound Power and Light }\end{array}$ & $\begin{array}{l}4 \\
4 \\
4 \\
4\end{array}$ & $\begin{array}{r}22,888 \\
3,950 \\
2,075 \\
1,394\end{array}$ & 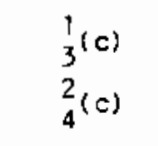 \\
\hline $\begin{array}{l}\text { C.P. National } \\
\text { SurprIse Valley Elec. Corp. } \\
\text { Unatllia Electr Ic Coop. } \\
\text { Col umbia Power Coop. } \\
\text { Wasco Electric Coop. }\end{array}$ & $\begin{array}{l}5 \\
5 \\
5 \\
5 \\
5\end{array}$ & $\begin{array}{r}22,915 \\
22,713 \\
15,966 \\
5,800 \\
1,665\end{array}$ & $\begin{array}{l}3 \\
i(c) \\
5 \\
2(c)\end{array}$ \\
\hline $\begin{array}{l}\text { Dougtas County PUD } \\
\text { Inl and Power and Light } \\
\text { Col unbia REA } \\
\text { Pacific Power and Light }\end{array}$ & $\begin{array}{l}6 \\
6 \\
6 \\
6\end{array}$ & $\begin{array}{r}28,977 \\
10,077 \\
4,534 \\
2,030\end{array}$ & $\begin{array}{l}1 \\
2 \\
3(c) \\
4\end{array}$ \\
\hline $\begin{array}{l}\text { Idaho Power Company } \\
\text { Wash ington Water Power } \\
\text { Utah Power and Light }\end{array}$ & $\begin{array}{l}7 \\
7 \\
7\end{array}$ & $\begin{array}{l}28,145 \\
27,520 \\
18,983\end{array}$ & $\frac{6}{8}(c)$ \\
\hline Montana Power Company & 7 & 11,613 & $10^{(c)}$ \\
\hline $\begin{array}{l}\text { Salmon River Coop. } \\
\text { Fi athead irrig. Power Roject }\end{array}$ & $\begin{array}{l}7 \\
7\end{array}$ & $\begin{array}{l}9,589 \\
8,587\end{array}$ & $\begin{array}{l}5 \\
2\end{array}$ \\
\hline $\begin{array}{l}\text { Rovalli County Elec, Coop. } \\
\text { Kootenoi REA } \\
\text { Flathead Electrlc Coop. } \\
\text { Pacific Power and LIght }\end{array}$ & $\begin{array}{l}7 \\
7 \\
7 \\
7\end{array}$ & $\begin{array}{l}6,432 \\
6,405 \\
4,330 \\
1,611\end{array}$ & $\begin{array}{l}7 \\
4 \\
9\end{array}$ \\
\hline $\begin{array}{l}\text { Puget Sound Power and Light } \\
\text { Consumers Power inc. } \\
\text { Douglos El ectrlc Coop. } \\
\text { Wahkiakum County PuD }\end{array}$ & $\begin{array}{l}8 \\
8 \\
8 \\
8\end{array}$ & $\begin{array}{r}12,543 \\
5,982 \\
2,251 \\
721\end{array}$ & 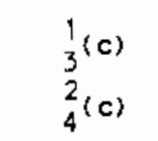 \\
\hline
\end{tabular}

(a) Low MW Group = Utilities that have a megawatt hour (MWh) load of less than 30,000 Mith within a given geographic stratum.

(b) Selection order based on the order in which the random numbers, corresponding to cumulative PSU usage percentages, wera drawn.

(c) Al ternates to be Included in the sample only if randamiy selected designated utilities choose not to participote in the study. 
whose operations are located in G-stratum 5 were substituted in the sampling process for C.P. National irrigation customers.

5. Idaho Power's response allocation in Geographic Stratum 7 was replaced by Washington Water Power because of uncertainty about whether Idaho Power could provide customers from this G-stratum for inclusion in the survey sample.

6. Clallam County Public Utility District was substituted in G-stratum 8 because for various reasons, cooperation in the study could not be obtained from Puget Sound Power and Light, Consumers Power Incorporated and Wahkiakum Public Utility District.

After these modifications to the initial PSU utility selection, the utilities selected for the irrigation survey sample were those listed in Table 3.6. Note from Table 3.6 that several PSUs, in different G-strata were selected for some utilities. The 40 utilities (52 PSU) selected for the irrigation survey sample comprised approximately 97 percent of 1980 irrigation electrical demand in the Pacific Northwest region. They represent every irrigation area in the region, include both private (investor-owned) and public utilities, and include both small and large utilities.

\subsection{INITIAL ALLOCATION OF CUSTOMER INTERVIEWS (ESUS) AMONG UTILITIES (PSUS)}

In this study, allocation of a desired level of 1700 successfully completed telephone interviews among selected utilities was performed based on the relative sizes of the utilities' regional irrigation loads.

\subsubsection{High and Low MWh Group Interview Allocations}

A preliminary allocation of interviews was performed using 1980 irrigation load data. (a) This allocation resulted in Idaho Power Company receiving over 500 of the total responses. Allocating over 500 responses to Idaho Power would

(a) Unpublished data developed by Northwest Economic Associates and supplied by Fred Gordon, Conservation Planning, Bonneville Power Administration. 
TABLE 3.6. Utilities Selected for Irrigation Survey Sample

\begin{tabular}{|c|c|c|}
\hline Utility Selected & Mwh Group ${ }^{(a)}$ & G-Strata Covered ${ }^{(b)}$ \\
\hline 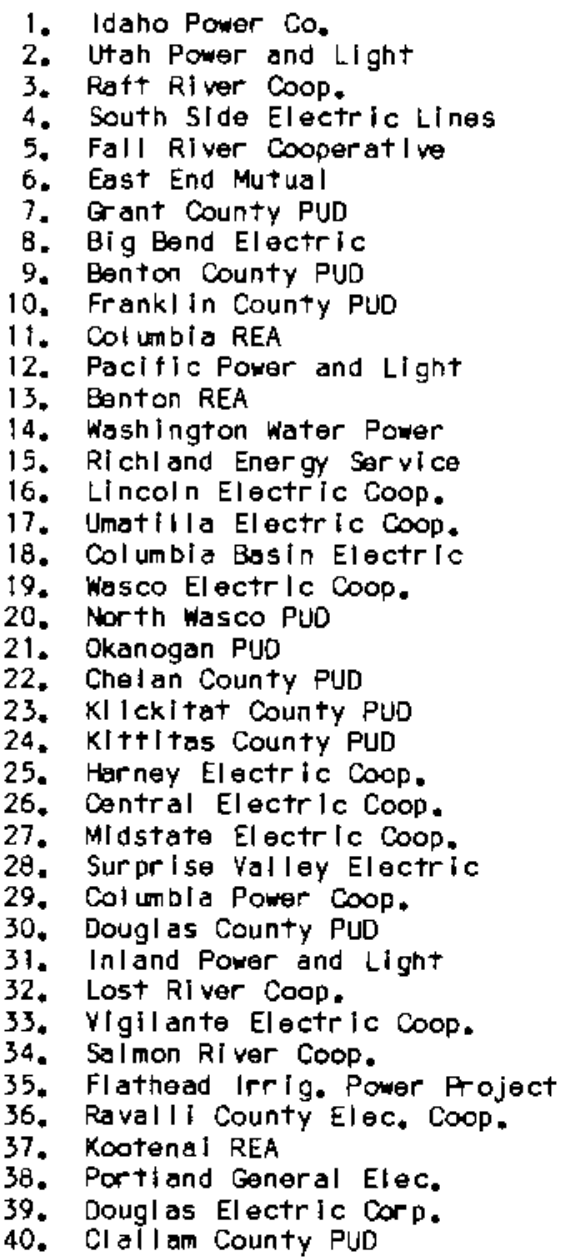 & $\begin{array}{l}\text { High } \\
\text { High } \\
\text { High } \\
\text { Low } \\
\text { Low } \\
\text { Low } \\
\text { High } \\
\text { High } \\
\text { HI gh } \\
\text { HIgh } \\
\text { High } \\
\text { HIgh } \\
\text { High } \\
\text { High } \\
\text { Low } \\
\text { HI gh } \\
\text { High } \\
\text { High } \\
\text { Low } \\
\text { Low } \\
\text { High } \\
\text { High } \\
\text { Low } \\
\text { Low } \\
\text { HIgh } \\
\text { High } \\
\text { HI gh } \\
\text { Low } \\
\text { Low } \\
\text { LOw } \\
\text { Low } \\
\text { HIgh } \\
\text { High } \\
\text { Low } \\
\text { Low } \\
\text { Low } \\
\text { Low } \\
\text { Hlgh } \\
\text { Low } \\
\text { Low }\end{array}$ & 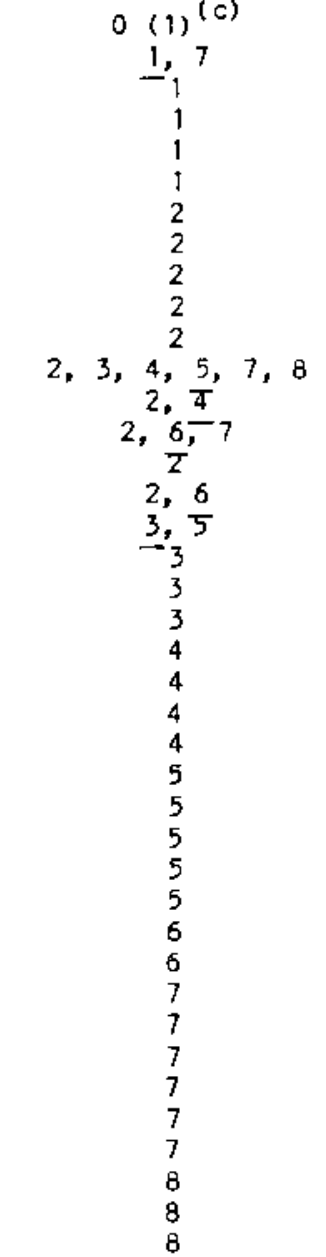 \\
\hline
\end{tabular}

\footnotetext{
(a) Utllities with 1980 irrlgation lads within a goographle strata that exceeded 30,000 Mwh we placed in the hlgh Mwh group, and utilities with loads less than $30,000 \mathrm{Mwh}$ were placed in the low Miwh group.

(b) The G-stratum with the largest usage for the utility is underI ined.

(c) Idaho Pover Company's Irrigation load is primarlly located in Geographic Stratum 1, but its relat I ve Irrigation load is so large that it was assigned its ow stratum.
} 
not allow for other utilities to be adequately represented in the surveys, so this utility's response allocation was specified at 200. Even at 200, Idaho Power's interview allocation remained the largest in the irrigation survey sample.

The remaining 1500 required successful responses for the survey were divided between the high MWh group and the low MWh group based on the percentage of total 1980 regional irrigation load (excluding Idaho Power Company's load) that the two groups comprised. This resulted in approximately 1300 successful responses being allocated to the remaining high MWh group utilities because these utilities comprised 87 percent of total irrigation load in 1980 (excluding Idaho Power). The remaining 200 successful responses were allocated to utilities in the low MWh group.

\subsubsection{Individual Utility Interview Allocations}

Analysis of 1984 irrigation load data obtained from utilities in conjunction with selecting customers (ESUs) for the survey sample (ESU sampling procedures are discussed in Chapter 4.0 of this report) revealed that billed irrigation loads for some utilities had decreased significantly from those reported to BPA for 1980, while other utilities' irrigation loads had increased. Thus, it was decided that 1984 data should be used to allocate survey responses to individual utilities within the high MWh and low Mh groups.

Total utility 1984 irrigation load data for 35 of the 40 utilities selected for the survey sample were obtained either through a listing provided by the utilities or over the telephone. The only utilities for which 1984 irrigation load data could not be obtained prior to response allocation were the following:

- Midstate Electric Cooperative

- Portland General Electric

- Clallam County PUD

- Douglas Electric Cooperative

- Flathead Irrigation and Power Project 
When combined, these five utilities comprise less than four percent of Pacific Northwest regional irrigation load. Irrigation load data from 1980 was used to approximate the proper sample allocation for these utilities.

After 1984 irrigation load data had been collected, initial survey response allocations to utilities within the high group were made based on the percentage of total 1984 high group irrigation load comprised by each utility. The only exception to this allocation method was Idaho Power Company, which continued to receive an allocation of 200 successful responses. The initial response allocations for the selected high group utilities are presented in Table 3.7. As will be explained in Chapter 5, it was necessary in sone cases to modify these initial response allocations when irrigation account load distribution data were received from the various utilities.

As reported in Table 3.6, six of the utilities selected for inclusion in the irrigation survey sample cover multiple G-strata. For three of these utilities, it was not possible to separate 1984 customer loads into different G-strata prior to sample selection. These utilities and the G-strata that they cover are as follows:

- Utah Power and Light - high MWh group for G-stratum 1, low MWh group for G-stratum 7

- Lincoln Electric Coop. - high MWh group for G-stratum 6, low MWh group for G-stratum 2

- Umati1la Electric Coop. - high MWh group for G-stratum 3, low MWh group for G-stratum 5

Although sample allocations representing both high and low MWh group PSUs were made for these utilities, the lack of customer data by G-stratum precluded sample selection by G-stratum. Thus, the low MWh group PSUs were combined with the high MWh group PSUs for these utilities, resulting in a reduction of three in the number of PSUs. When customer responses are obtained for these utilities, any customers found to lie in a low MWh group G-stratum will be placed in that stratum. 
TABLE 3.7. Initial AlTocated Successful Telephone Responses for High Group Utilities in Irrigation Survey Sample

\begin{tabular}{|c|c|c|c|}
\hline Utility & G-Stratum & $\begin{array}{l}\text { Mwh Consumption } \\
\text { Used in Sample } \\
\text { Allocation }\end{array}$ & $\begin{array}{r}\text { Initial } \\
\text { Allocated } \\
\text { Responses } \\
\end{array}$ \\
\hline Idaho Power Co. & 0 & $1,489,502$ & 200 \\
\hline Utah Power and Light & 1 & 290,506 & 148 \\
\hline Raft River Coop. & 1 & 94,253 & 51 \\
\hline Grant County PUD & 2 & 321,985 & 175 \\
\hline Big Bend Electric & 2 & 216,041 & 117 \\
\hline Benton County PUD & 2 & 234,182 & 127 \\
\hline Franklin County PUD & 2 & 93,308 & 51 \\
\hline Col umbia REA & 2 & 107,400 & 58 \\
\hline Pacific Power and Light & 2 & 30,683 & 17 \\
\hline Benton REA & 2 & 21,582 & 12 \\
\hline Washington Water Power & 2 & 31,918 & 17 \\
\hline Umatilla Electric Coop. & 3 & 234,380 & 127 \\
\hline Columbia Basin Electric & 3 & 30,748 & 17 \\
\hline Pacific Power and Light & 3 & 84,118 & 46 \\
\hline Okanogan PUD & 4 & 43,786 & 24 \\
\hline Pacific Power and Light & 4 & 97,182 & 53 \\
\hline Benton REA & 4 & 37,292 & 20 \\
\hline Chelan County PUD & 4 & 31,472 & 17 \\
\hline Pacific Power and Light & 5 & 118,234 & 64 \\
\hline Surprise Valley Electric & 5 & 33,634 & 20 \\
\hline Central Electric Coop. & 5 & 36,291 & 20 \\
\hline Midstate Electric Coop. & 5 & 34,576 & 16 \\
\hline Harney Electric Coop. (Nevada) & 5 & 40,941 & 22 \\
\hline Washington Water Power & 6 & 44,477 & 22 \\
\hline Lincoln Electric Coop. & 6 & 54,492 & 30 \\
\hline Lost River Electric & 7 & 20,530 & 12 \\
\hline Vigilante Electric & 7 & 35,637 & 19 \\
\hline Portland General Electric & 8 & 38,000 & 21 \\
\hline Pacific Power and Light & 8 & 20,934 & 12 \\
\hline TOTAL INITIAL RESPONSE ALLOCATI & & $\overline{3,968,084}$ & $\overline{1,535}$ \\
\hline
\end{tabular}

(a) MWH consumption levels for sample allocation are equal to 1984 irrigation loads for all utilities except Portland General Electric.

(b) Idaho Power Company was assigned a response allocation of only 200 because, based on the relative size of its irrigation load (1.5 million MWh), over 500 of the 1700 total responses would have been allocated to Idaho Power. 
Initial response allocations for PSUs in the low MWh group were made in two steps. First, the percentages of total 1980 low MWh group consumption comprised by all low group utilities in each G-stratum were calculated. These percentages were used to allocate the 200 required responses for the low group among G-strata. The second step was to allocate the required responses for each G-stratum among selected utilities in each G-stratum using 1984 load data.

The calculations used in initially allocating responses to low MWh group utilities are illustrated in Table 3.8. The percentages of total low group 1980 MWh load comprised by all low group utilities in each G-stratum are shown

TARLE 3.8. Allocated Successful Telephone Responses for Low Group Utilities in Irrigation Survey Sample

\begin{tabular}{|c|c|c|c|c|c|}
\hline G-Stratum & $\begin{array}{l}\text { L of Total } 1980 \\
\text { Low Group Logd } \\
\text { in G-Stratum }\end{array}$ & $\begin{array}{l}\text { Low Group } \\
\text { G-Stratum } \\
\text { All ocation }\end{array}$ & Selected Utility Name & $\begin{array}{l}\text { g of } 1984 \\
\text { Salected } \\
\text { Load (b) }\end{array}$ & $\begin{array}{l}\text { Initial } \\
\text { utility } \\
\text { Response } \\
\text { Allocation }\end{array}$ \\
\hline 1 & 15.3 & 31 & $\begin{array}{l}\text { Fall River } \\
\text { East End Mutual } \\
\text { South Side Electric }\end{array}$ & $\begin{array}{l}45.2 \\
11.9 \\
42.9\end{array}$ & $\begin{array}{r}14 \\
4 \\
13\end{array}$ \\
\hline 2 & 2.9 & 6 & $\begin{array}{l}\text { Rlchland Energy Service } \\
\text { LIncol n Electric Coop. }\end{array}$ & $\begin{array}{l}58.4 \\
41.8\end{array}$ & $\begin{array}{l}4 \\
3\end{array}$ \\
\hline 3 & 5.0 & 10 & $\begin{array}{l}\text { Wasco Electric } \\
\text { North Wasco Pud }\end{array}$ & $\begin{array}{l}86.6 \\
13.4\end{array}$ & 9 \\
\hline 4 & 7.9 & 16 & $\begin{array}{l}\text { Klickitat PUD } \\
\text { KIt+itas PUD }\end{array}$ & $\begin{array}{l}85.0 \\
15.0\end{array}$ & $\begin{array}{r}14 \\
2\end{array}$ \\
\hline 5 & 16.8 & 34 & $\begin{array}{l}\text { Umatilla Electric } \\
\text { Harney Electric (Oregon) } \\
\text { Col umbla Power Coop. }\end{array}$ & $\begin{array}{l}41.2 \\
47.1 \\
11.8\end{array}$ & $\begin{array}{r}14 \\
16 \\
4\end{array}$ \\
\hline 6 & 11.4 & 23 & $\begin{array}{l}\text { Douglas County PUD } \\
\text { Inl and } P \text { and } L\end{array}$ & $\begin{array}{l}81.3 \\
18.7\end{array}$ & $\begin{array}{r}19 \\
4\end{array}$ \\
\hline 7 & 31.8 & 64 & $\begin{array}{l}\text { Washington Water Power } \\
\text { Utah Power and LIght } \\
\text { Salmon RI ver Coop. } \\
\text { Fl athead Power Aoject } \\
\text { Ravall E Electrlic } \\
\text { Kootenai REA } \\
\text { Paciflc Power and Light }\end{array}$ & $\begin{array}{r}35.0 \\
21.0 \\
11.2 \\
12.0 \\
9.7 \\
9.0 \\
1.9\end{array}$ & $\begin{array}{r}22 \\
13 \\
7 \\
8 \\
6 \\
6 \\
2\end{array}$ \\
\hline 8 & 8.9 & $\uparrow 8$ & $\begin{array}{l}\text { Douglas Electric Coop. } \\
\text { Clallam County PUD }\end{array}$ & $\begin{array}{l}30.7 \\
69.3\end{array}$ & $\begin{array}{r}6 \\
12\end{array}$ \\
\hline TOTALS & 100.0 & 202 & & & 203 \\
\hline
\end{tabular}

(a) Total 1980 irrigation load for low group utilitiles was $420,964 \mathrm{mwh}$.

(b) Represents percent of total load for all utilities selected In a G-stratum comprised by each selected utility. 
in the second column of Table 3.8. These percentages were used to derive the low group G-strata allocations shown in the third column using a total response allocation for all low group G-strata of 200. The percentages compried by each selected utility of the combined 1984 load for all selected low group utilities in each G-stratum are shown in the fifth column of Table 3.8. These were used in dividing the G-strata allocations among selected utilities. The initial response allocations based on these percentages for the selected low group utilities are shown in the last column of Table 3.8. In many cases, adjustments to the initial response allocations shown in Table 3.8 were necessary in order to obtain a sample with improved statistical properties that conformed to the irrigation account Wh distribution characteristics of the various utilities. A description of these adjustments is presented in Chapter 5. 


\subsection{GENERAL SAMPLE SPECIFICATION AND SELECTION AT THE ESU (IRRIGATION CUSTOMER) LEVEL}

Proper selection of irrigation customers for the irrigation survey sample required that the following tasks be performed:

1. specification of sampling criteria for selecting customers for the sample

2. development of sampling methods for identifying/selecting customers for the sample according to the sampling criteria.

The specific activities involved in performing these tasks are described in this chapter.

\subsection{ESU (IRRIGATION CUSTOMER) SAMPLE SPECIFICATION}

The sampling methods developed in this study are based on a sampling theory described by Roger L. Wright (Wright 1982). This article demonstrates the improvement in precision of estimation (of MW demand) when the population (customers of a utility) is separated into usage strata (U-strata) that account for equal percentages of the total utility MWh usage. This theory was combined with sampling the high MWh usage stratum customers with probability one (i.e., al high usage stratum customers are selected for the sample) in developing the sampling methodology for the BPA irrigation customer survey.

After performing some preliminary investigation, it was found that not all utilities would be able to construct a listing of their individual irrigation customers' kWh consumption. Therefore, sampling for these utilities had to be done from a listing of billed meters. This complicated the theory, but after the survey has been administered, the billing record information needed for "post-stratification" based on customer usage will be available to classify the respondents into their appropriate U-strata.

In order to develop a basis for sampling irrigation customers according to load, 1984 irrigation account load data for 14 utilities were obtained. These 
data provided listings for 19 PSUs with at least one utility listing of indi-

vidual customer kwh consumption for every G-stratum except Stratum 8. The data a) so provided at least one listing of metered account kwh consumption for every G-stratum. Thus, these data allowed for design of the customer sampling frame to incorporate load data from every G-stratum and to be flexible enough to be applied to either individual customer or metered account data.

Data from these 19 purposely selected PSUs were used to define the cut points for six MWh usage strata. The sixth stratum is the high Muth usage stratum, consisting of all customers using at least $500 \mathrm{MWh}$ or metered account; above 300 MWh for some G-strata. The low-usage group was defined as consisting of all customers or meters not in the high-usage stratum. This group was partitioned into five low-usage strata. Each of the five low U-strata accounted for 20 percent of the total MWh remaining in the purposely selected utilities after the Mwh in the high stratum were taken out.

The cut points for U-strata change for different G-strata, but all have an upper limit that defines the high-usage stratum of $500 \mathrm{MWh}$ for customers and 300 or $500 \mathrm{Mth}$ for metered accounts. The $500-\mathrm{M} / \mathrm{kh}$ limit was selected because it provided some large customers for all utilities that were analyzed without exceeding the tentative sample size allocation for the utilities.

Table 4.1 presents definitions of the upper limits (in Mwh) for the low Ustrata calculated in each G-stratum for both the customer (C) data and the meter (M) data. These definitions were used as the criteria for selecting irrigation accounts for the irrigation survey sample from among the utilities listed at the bottom of Table 4.1. The definitions presented in Table 4.1 were also used as sampling criteria for utilities for which MWh load data were not available to derive utility specific cut points based on 20 percent increments in load. In addition to the 14 utilities listed at the bottom of Table 4.1, the utilities for which cut points specific to their customers' load character. istics were defined include:

- Idaho Power Company

- Benton Rural Electric Association

- Chelan County PIJD

- Ravalli County Electric Coop. 
TABLE 4.1. Definition of Upper Limits in MWh for Low Usage Strata in Each Geographical Stratum

\begin{tabular}{|c|c|c|c|c|c|c|c|c|c|}
\hline \multirow[b]{3}{*}{$U-S t .(a)$} & \multirow{3}{*}{$\begin{array}{l}\text { Cumulative } \\
\text { Percentage }\end{array}$} & \multicolumn{8}{|c|}{ G-Stratum } \\
\hline & & \multicolumn{2}{|l|}{$\overline{1}$} & \multicolumn{2}{|c|}{2} & \multicolumn{2}{|c|}{3} & \multicolumn{2}{|c|}{4} \\
\hline & & $c(b)$ & $\bar{M}$ & $C$ & $M$ & C & $M$ & C & $M$ \\
\hline 1 & $20 \%$ & $125^{(c)}$ & 70 & 70 & 25 & 45 & 25 & 30 & 15 \\
\hline 2 & $40 \%$ & 225 & 150 & 120 & 50 & 125 & 100 & 65 & 30 \\
\hline 3 & $60 \%$ & 300 & 250 & 200 & 100 & 240 & 200 & 125 & 50 \\
\hline 4 & $80 \%$ & 400 & 350 & 300 & 170 & 375 & 350 & 240 & 110 \\
\hline 5 & $\operatorname{Max}$ & 500 & 500 & 500 & 500 & 500 & 500 & 500 & 500 \\
\hline & $\begin{array}{l}\text { Based on } \\
\text { Utility }\end{array}$ & RFTR & UTAH & $\begin{array}{l}\text { GRNT } \\
\text { COLR }\end{array}$ & PP\&L & $\begin{array}{l}\text { UMAT } \\
\text { WASC }\end{array}$ & PP\&L & $O K P$ & PP\&L \\
\hline
\end{tabular}

\begin{tabular}{|c|c|c|c|c|c|c|c|c|c|}
\hline \multirow[b]{3}{*}{ U-St. } & \multirow{3}{*}{$\begin{array}{l}\text { Cumulative } \\
\text { Percentage }\end{array}$} & \multicolumn{8}{|c|}{ G-Stratum } \\
\hline & & \multicolumn{2}{|c|}{5} & \multicolumn{2}{|c|}{6} & \multicolumn{2}{|c|}{7} & \multicolumn{2}{|c|}{8} \\
\hline & & $C$ & $M$ & $C$ & $M$ & $C$ & $M$ & $\mathrm{C}$ & $M$ \\
\hline 1 & $20 \%$ & 70 & 25 & 30 & 100 & 65 & 15 & 30 & 10 \\
\hline 2 & $40 \%$ & 125 & 50 & 92 & 200 & 110 & 35 & 65 & 20 \\
\hline 3 & $60 \%$ & 200 & 85 & 184 & 275 & 175 & 60 & 125 & 40 \\
\hline 4 & $80 \%$ & 275 & 160 & 320 & 375 & 285 & 250 & 240 & 70 \\
\hline \multirow[t]{2}{*}{5} & $\operatorname{Max}$ & 500 & 500 & 500 & 500 & 500 & 300 & 500 & 300 \\
\hline & $\begin{array}{l}\text { Based on } \\
\text { Utility }\end{array}$ & $\begin{array}{l}\text { SRPV } \\
\text { HRNY }\end{array}$ & PP\&L & WWP & $\begin{array}{l}\text { LINC } \\
\text { DOUG }\end{array}$ & VIGL & PP\&L & OKP & PP\&L \\
\hline
\end{tabular}

\footnotetext{
(a) U-St. = Usage Stratum

(b) $C$ is for customer data and $M$ is for meter data.

(c) Numbers shown represent maximum MWh limits for placing an irrigation account within a geographic stratum into its proper usage stratum.

(d) The letter codes refer to the following utilities:

RFTR - Raft River Coop. OKP - OKanogan PUD

UTAH - Utah Power and Light SRPV - Surprise Valley

GRNT - Grant County PUD HRNY - Harney Elec. Coop.

COLR - Columbia REA WWP - Washington Water Power

PP\&L - Pacific Power and Light LINC - Lincoln Coop (WA)

UMAT - Umatilla Electric Coop. DOUG - Douglas County PUD (WA)

WASC - Wasco Electric Coop. VIGL - Vigilante Elec. Coop.
} 
For the other 22 utilities included in the sample, "representative" cut points were defined based on the G-stratum cut points 1 isted in Table 4.1 and used in sample selection. The assumption used is that the usage distributions for utilities where representative cut points were used in sample selection are similar to those for the utilities within the same G-stratum upon which the cut-points were based. The utilities for which utility-specific cut points were defined represented 78 percent of Pacific Northwest regional irrigation load and the use of "representative" cut points was necessary for utilities comprising 22 percent of regional load.

The only exception to the cut point for the high U-strata shown in Table 4.1 was for Idaho Power Company, where the total number of customers using 500 MWh or more was 700 , exceeding the utility's response allocation of 200 by 500 customers. Idaho Power's high stratum cut point was raised to $2000 \mathrm{MWh}$, which resulted in 121 customers being included in this stratum and sampled with probability one. The other U-strata cut points for ESU stratification within Idaho Power were as follows:

- U-stratum 5, maximum $=2000 \mathrm{MWh}$

- U-stratum 4, maximum $=1270 \mathrm{MWh}$

- U-stratum 3, maximum $=800 \mathrm{MWh}$

- U-stratum 2, maximum $=500 \mathrm{MWh}$

- U-stratum 1, maximum = $250 \mathrm{MWh}$

PNL could not obtain preliminary customer kWh consumption data from Portland General Electric, the utility selected to represent G-stratum 8 . Therefore, customer cut points from G-stratum 4 were used to define ESU Ustrata for G-stratum 8. G-stratum 8 is expected to have smaller usage per customer than most G-strata and the distribution for G-stratum 4 indicates that relatively low-usage customers are predominant.

\subsection{GENERAL DESCRIPTION OF SAMPLING METHODS FOR ESU SELECTION}

In general, the sampling methods developed for use in this study require that the person doing the sampling (PNL or utility) have: a listing of accounts (customer or meter), the appropriate G-strata cut points from Table 4.1, and $n_{r}$, the allocated sample response size for the utility from 
Table 3.7 or 3.8. The sampling task becomes more complicated as the listings change from the ideal customer listing sorted by (aggregated) total MWh usage of individual customers to unsorted meter data. The methods have step-by-step procedures for partitioning the total adjusted sample size to the U-strata and systematically (with a random start) selecting accounts from the listing. When accounts are for individual meters, cross-checking of names and addresses associated with the billings for the meters is required to come up with a sample listing free of duplicates. In addition, some information about the number of meters per customer in each of the MWh load strata is necessary in order to select the appropriate number of custoners from each stratum for the survey sainple.

The general procedures incorporated in the sampling methods are as follows:

Let $n_{r}$ be the total number of allocated responses for a utility. Let $n_{H}$ be the number of customers using at least $500 \mathrm{MWh}$. These custoners will be selected with probability one. Then

$$
n_{L}=n_{r}-n_{H}
$$

is the number of responses needed from the five low-usage strata. In order to account for non-response and listing errors, let

$$
n_{L S}=\left[1.333 n_{L}\right]_{I}+1
$$

truncated to the whole number. Then the required equal sample size in each of the five low-usage strata is

where

$$
n_{u}=n_{i} / 5
$$

$$
n_{L}^{\prime}=n_{L S}+c_{5}
$$


and

$c_{5}$ is an integer, $(0,1,2,3$, or 4$)$ that makes $n_{L}$ exactly divisible by 5 .

The adjustment for listing and non-response error of $\left[1.333 n_{L}\right]_{I}+1$ truncated to the whole number was chosen based on an expected response rate of 80 percent and a listing error rate of 5 percent. Given these assumptions, the sample size, $n_{s}$, required to assure $n_{r}$ responses is

$$
n_{s}=n_{r} / 0.75=1.333 n_{r} *
$$

To clarify these ideas, consider an example using data from Umatilla Electric Cooperative. This utility had a total usage in 1984 of 234,380 MWh; and 1003 jrrigation usage meters billed to 448 customers. The preliminary customer respondent allocation for Umatilla (before CP National's allocation in G-stratum 5 was added) was:

$$
n_{r}=120 \text { customers. }
$$

There were $n_{H}=51$ high-usage stratum customers so that

$$
n_{L}=120-51=69 \text { low-usage group customers }
$$

and

$$
n_{L S}=[(1.333) 69]_{I}+1=91+1=92 .
$$

There are then $397,(448$ - 51), customers available for sampling for the low group representatives. Then

$$
n_{L}^{\prime}=92+3=95
$$

and

$$
n_{u}=95 / 5=19
$$

customers to be sampled in each low-usage stratum. 
A modification to $n_{u}$ for Umatilla is required since the 60 to 80 percent and 80 to 100 percent low-usage strata have 14 and 10 customers instead of the required 19. The resolution is made through several adjusting calculations. The adjusting calculations are based on sampling the strata with NCUST less than $n_{u}$ with probability one, thus reducing the upper limit for the high group to customers with consumption in excess of 240 MWh. For Umatilla Electric,

$$
n_{L}(\operatorname{adj})=120-75=45
$$

and

$$
n_{L S}(\operatorname{adj})=[(1.333) 45]+1=60
$$

Then

$$
n_{u}^{\prime}=60 / 3=20
$$

since the 60 sampled customers for the low group now represent only 3 strata. Thus, for Umatilla, all 75 customers with usage of 240 Mwh or greater will be selected, and at least 20 customers will be selected from each of the 3 lowest usage strata (see Table 4.2).

The mechanism for selecting customers from strata where all customers are not sampled is to calculate the required sampling interval for each U-stratum as

$$
I_{u}=\left[\operatorname{NCUST}_{u} / n_{u}^{\prime}\right]
$$

truncate to the whole number, and enter the result in the Sampling Interval column. Then every $I_{U}$-th customer in the listing that falls in the U-stratum is selected. For Umatilla, the sampling interval is 1 for the 40 to 60 percent U-stratum, $(25 / 20), 2$ for the 20 to 40 percent J-stratum, and 14 for the 0 to 20 percent U-stratum. This procedure is applicable to sorted customer listings, and, by skipping customers not in the U-stratum being sampled for, to unsorted customer listings. 
IABLE 4.2. Example of Sample Allocation for Customer Data (Umatilla Electric)

\begin{tabular}{|c|c|c|c|c|c|c|c|}
\hline Usage Stratum & $\begin{array}{l}\text { MWh U-St. } \\
\text { Limit }\end{array}$ & NCUST & $\underline{n}_{u}$ & ${ }^{n_{r u t}}$ & $n_{r u}^{\prime}$ & $\underline{n_{u}^{\prime}}$ & $\begin{array}{l}\text { Sampling } \\
\text { Interval } \mathrm{I}_{\mathrm{U}} \text { : }\end{array}$ \\
\hline $0-20 \%$ & 45 & 295 & 19 & 14 & 15 & 20 & 14 \\
\hline $20-40 \%$ & 125 & 53 & 19 & 14 & 15 & 20 & 2 \\
\hline $40-50 \%$ & $\underline{240}$ & 25 & 19 & 14 & 15 & $\underline{20}$ & 1 \\
\hline $60-80 \%$ & 300 & 14 & 19 & 14 & (14) & 0 & -- \\
\hline $80-100 \%$ & 500 & 10 & $\underline{19}$ & 14 & $(10)$ & $\underline{0}$ & - \\
\hline Low Stratum Total & & 397 & 95 & 70 & 45 & 60 & \\
\hline High Stratum Total & & 51 & 51 & 51 & 75 & 75 & \\
\hline Total All Strata & & 448 & 146 & 121 & 120 & 135 & \\
\hline
\end{tabular}

where NCUST = Number of customers in each U-stratum.

$n_{u}=$ Preliminary number of customers from each U-stratum to be included in the survey sample.

$n_{r u}=$ Preliminary number of customers from each U-stratum for which successful responses to the telephone survey are required.

$n_{r u}^{\prime}=$ Adjusted number of required successful responses from each U-stratum.

$\mathrm{n}_{u}^{\prime}=$ Adjusted number of customers from each U-stratum to be included in the survey sample.

Grant County PUD in geographical stratum 2 provides a more straightforward example. It had a more equal split of total MWh usage to the high (43\%) and low (57\%) MWh usage groups than did Umati11a (where $90.7 \%$ of the total MWh was accounted for by the high group). For Grant, the total MWh usage in 1984 was 321,986 by 2,148 customers through 3,324 meters. The allocated sample size was 175 customers. There were $n_{H}=120$ customers using at least $500 \mathrm{MWh}$, leaving $n_{L}=55$ customers to represent the low group. Then

$$
n_{L S}=[1.333(55)]+1=75=n_{L}^{\prime}
$$

and

$$
n_{u}=75 / 5=15
$$


customers to be sampled in each low-usage stratum. Each low-usage stratum had enough customers to cover a sample size of 15 .

It should be noted that the sampling method described above were the ideal method that was used whenever individual customer consumption data were available to PNL. Such data were available for 28 utilities included in the sample. However, the specific sampling method used for each utility was determined by the type of account listing available to PNL.

When a utility could not list consumption by customers, the potential for multiple meters per customer, and consequently, multiple sampling of the same customer, was high. For eight utilities that provided both customer and meter data, the average number of meters per customer ranged from 1.55 to 2.79 , and the average for all 8 utilities was 2.3 meters per customer. Individual customers had as many as 43 meters, but most customers had only one meter. Having to use meter, rather than customer listings as the sampling list creates theoretical statistical problems, and requires that different sampling methods than those applied to customer consumption data be used.

The sampling procedures developed in this study for selecting customers for the survey sample from metered data account for the problems introduced by multiple meters by utilizing assumptions about the number of meters per customer in the calculations.

Data from seven utilities that provided both meter and customer data were used to determine factors for expanding customer sample sizes to the number of meters expected to be typically required to provide the needed individual customers. The average number of meters per customer in each U-stratum is given in Table 4.3 for the seven utilities. The last column has the expansion weights $\left(E_{u}\right)$ used for each statum. These expansion weights are approximately the same as the (weighted by NCUST) U-strata averages for the number of meters per customer.

The general procedures developed for sample selection from metered data will be described using an example for Pacific Power and Light in G-stratum 4. 
TABLE 4.3. Average Meters per Customer

\begin{tabular}{|c|c|c|c|c|c|c|c|c|c|}
\hline \multirow[b]{2}{*}{ U-Stratum } & \multicolumn{7}{|c|}{ Utility (a) } & \multirow{2}{*}{$\begin{array}{l}\text { Stratum } \\
\text { Average }\end{array}$} & \multirow{2}{*}{$\begin{array}{l}\text { Weight } \\
\text { Used, } E_{u}(b)\end{array}$} \\
\hline & GRNT & TMAT & WASC & $\overline{O K P}$ & SPRV & HRNY & VIGL & & \\
\hline 1 & 1.08 & 1.11 & 1.34 & 1.19 & 1.28 & 1.66 & 1.49 & 1.31 & 1.3 \\
\hline 2 & 1.34 & 1.64 & 2.18 & 2.00 & 2.00 & 2.62 & 2.14 & 1.97 & 2.0 \\
\hline 3 & 1.68 & 2.93 & 3.54 & 2.31 & 2.71 & 3.08 & 2.38 & 2.66 & 2.5 \\
\hline 4 & 2.16 & 3.67 & 3.12 & 3.48 & 3.07 & 5.22 & 3.74 & 3.49 & 3.5 \\
\hline 5 & 2.55 & 3.62 & 6.40 & 4.55 & 4.06 & 5.50 & 5.65 & 4.32 & 4.3 \\
\hline 6 & 4.94 & 9.02 & 12.0 & 4.50 & 13.6 & 10.17 & 8.57 & 8.47 & 8.5 \\
\hline $\begin{array}{l}\text { Utility } \\
\text { Average }\end{array}$ & 1.55 & 2.24 & 2.04 & 1.56 & 2.07 & 2.79 & 2.28 & & \\
\hline NCUST & 2,148 & 448 & 161 & 842 & 394 & 127 & 387 & & \\
\hline NMETER & 3,324 & 1,003 & 329 & 1,395 & 814 & 354 & 883 & & \\
\hline
\end{tabular}

(a) See Table 4.1 for definition of utility codes.

(b) $E_{u}=$ Weighting factors for deriving number of meters to be selected for sample corresponding to the required number of customers in each stratum.

Pacific Power and Light (PP\&L) provided PNL with listings of meter billing data ordered by usage (MWh) for each of our G-strata 2, 3, 4, 5, 7 and 8. The listing for G-stratum 4 included accounts from PP\&L's Yakima, Sunnyside and Toppenish Service Districts. There were 4,548 meter accounts with total billed usage of $97,182 \mathrm{MWh}$.

The process for allocating the required customer sample size using metered account data is given in Table 4.4. The upper MWh limits for the U-strata were determined by counting the number of meters with billed usage in each of $27 \mathrm{MWh}$ ranges for usage less than 500 MWh and listing the exact usage for meters with at least $500 \mathrm{Mbh}$ billed. This frequency distribution was input to the computer, along with the MWh midpoints, and the cumulative MWh distribution calculated. Then, the MWh limits shown in Table 4.4 that split the usage less than $500 \mathrm{MWh}$ into the $5 \mathrm{U}$-strata, each accounting for about 20 percent of the low usage, were calculated.

The numbers in column NMET of Table 4.4 are the number of meters with usage in the range of Mwh determined by the limits; e.g., there were 2814 
meters billed between 0.1 and $15 \mathrm{MWh}$, 926 meters billed between 15 and $29 \mathrm{MWH}$, etc., up to 87 meters billed between 115 and $500 \mathrm{MWh}$. There were $M_{H}=6$ meters with billing greater than $500 \mathrm{MWh}$.

The rest of Table 4.4 is based on the calculations defined at the bottom of Table 4.4. First, the estimated number of customers in the high stratum, $n_{H}$, was calculated. This calculation was performed by multiplying the actual number of meters in the high stratum, $M_{H}$, by a conversion factor computed using data from Table 4.3. Then, the number of customers, $n_{u}$, required to assure the number of responses in each of the low MWh strata was calculated. This is 14, and is entered in the $n_{u}$ column.

The number of meters to be sampled, $M_{U}$, were then derived, using the expansion factors, $E_{u}$, given in Table 4.3. The sampling interval was calculated, and a random sample of metered accounts within each U-stratum was selected using a computerized random sampling method (MINITAB, SAMPLE command). Finally, the last column, nru, gives the number of distinct customers that must be contacted and respond to obtain the required number of responses. For example, in U-stratum 5, we want at least 14 ( $n_{u}$ ) distinct cus tomers from the 61 meter accounts selected for checking, and need 10 responses from these 14 .

The end product of the sampling procedures used in this study will be 1) a listing of the required number $\left(n_{u}\right)$ of irrigation customer names, 2) addresses, and 3) phone numbers (if available) that will almost certainly be more representative of the areas of interest to BPA than would a simple random sample of irrigators. As stated previously, it is necessary that the sampling methods used in this study be as scientifically valid as possible without imposing excessive data collection burdens on utility staff or creating any data confidentiality problems. The specific sampling methods used to select customers from each utility in the survey sample are designed to meet these requirements. These methods are described in the final chapter of this report. 
TABLE 4.4. Example of Sample Allocation for Meter Data, (PP\&L, G-stratum 4 data)

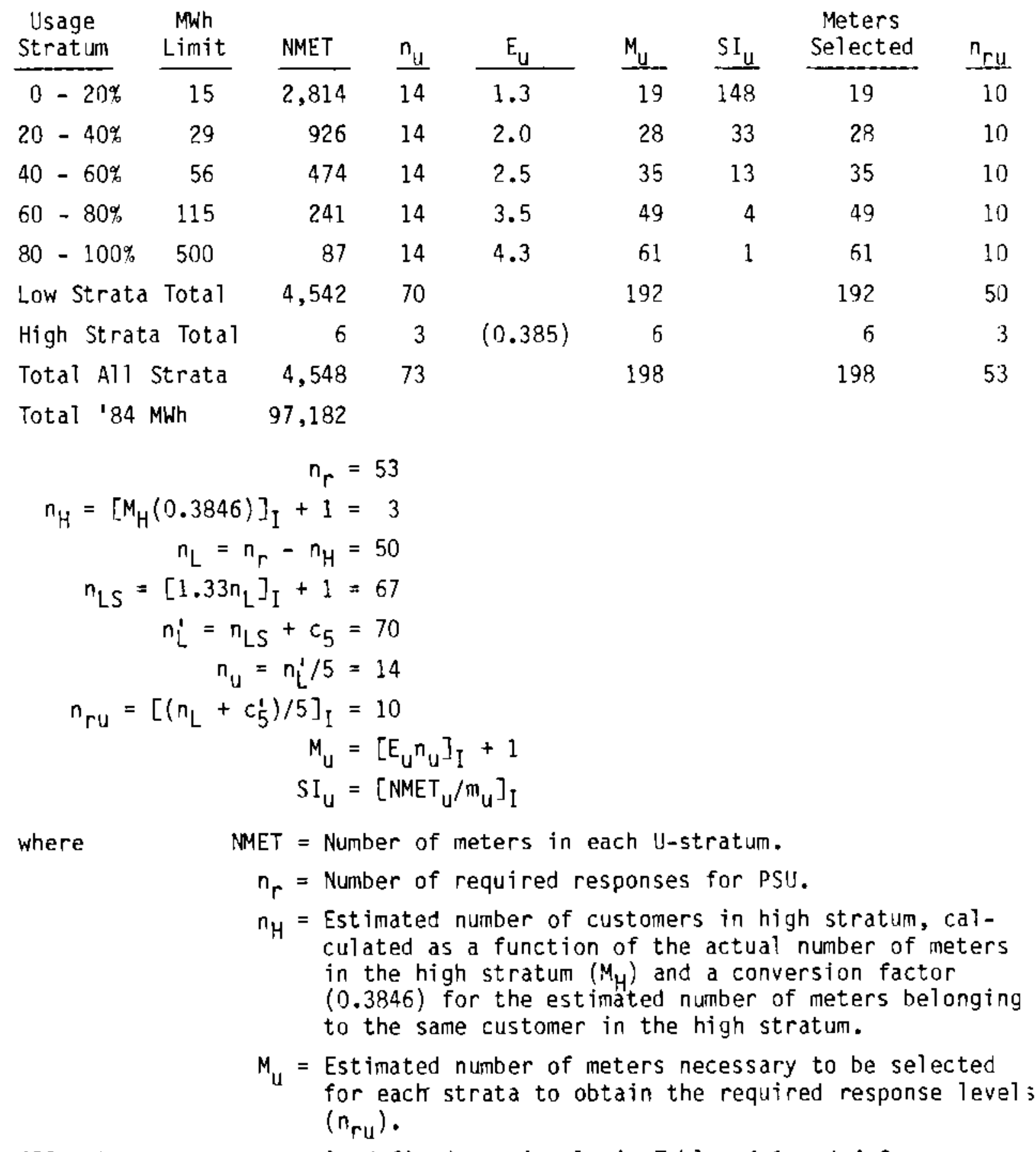

All other parameters = As defined previously in Tables 4.1 and 4.2. 


\subsection{UTILITY SPECIFIC SAMPLING METHODS}

Significant differences in billing record formats and data processing capabilities were found by contacting the 40 utilities included in the irrigation survey sample. These differences included the utility's ability to:

- readily provide an ordered listing of annual consumption data by individual irrigation customer

- readily provide annual consumption data by individual irrigation customer, but not readily order these data from highest to lowest or lowest to highest

- readily provide and order onty annual consumption data for metered irrigation accounts

- readily provide only unordered annual consumption data for metered irrigation accounts.

Several alternative sampling methods were developed for this study to deal with these differences. These methods are described in this chapter. Information on the specific sampling method used on each of the 40 utilities included in the study sample is presented. Adjustments in initial response allocations that were used in deriving final response allocations are described. The chapter concludes with a discussion of several problems that were incurred by using utility billing record data as the basis for sampling in the study and how these problems were addressed.

\subsection{SAMPLING METHOD ALTERNATIVES}

The sampling methods used in this study can be broadly separated into five alternative types. These alternatives are described in this section.

5.1.1 Method 1 - Sampling from an Ordered Customer List

This method was used when a utility could provide annual kwh consumption data by individual irrigation customer and could order these data from highest consumption to lowest or lowest to highest. ltilities with these characteristics provided PNL with an ordered listing of their irrigation customers' 1984 
irrigation consumption. Identities of the customers were masked from PNL to protect customer confidentiality.

When an ordered list sorted by customer kWh consumption was provided, lines were drawn at the appropriate U-stratum limits for the utility. The counts for the number of customers (NCUST) in each of the six U-strata were then easily obtained. After these counts were made, sampling was able to proceed exactly like the Imatilla Electric and Grant County PUD examples discussed in section 4.2. That is, $n_{u}$ (the number of customers from each low U-stratum to be included in the survey sample), the sampling interval, and other necessary elements of the sampling procedure were calculated, and customer identification numbers corresponding to the appropriate customers were selected.

The MWh consumption listings were then returned to the utilities, along with a request for the names, addresses and telephone numbers (if available) of the customers corresponding to the customer identification numbers. The requested information was then provided by the utilities and input into the survey sample records. More detailed information on the procedures used in Method 1 are presented in Appendix A, in the form of the worksheet that was used to implement Method 1 or Method 2 on all utilities that provided customer kWh consumption data to PNL.

5.1.2 Method 2 - Sampling From a Customer List Not Sorted by kWh Usage

This method was used when utilities were able to provide individual customer consumption amounts but did not have the capability to readily sort their kWh listings by amounts consumed. The selection results from using this method are similar to those of Method 1. However, slightly more effort was required by the PNL staff members performing the sampling because of the difficulty involved in tallying customers into six U-strata from an unsorted listing. The sampling was done a stratum at a time, skipping customers not falling within the limits for the stratum being worked on while counting to the $I_{u}$-th customer. After sampling was completed, the selected customer identification numbers were sent to the utilities with a request for the names, addresses and telephone numbers (if available) of the selected customers. The MWh consumption listings were also returned to the utilities at this time. 


\subsubsection{Method 3 -Sampling from an Ordered Meter Listing}

This method was used when a listing of metered irrigation account Mih consumption ordered either from lowest to highest or highest to lowest was available from data supplied by a utility. A line was drawn at the appropriate meter cut points and the number of meters (rather than the number of customers) in each U-Stratum was counted. Sampling then proceeded in the manner described in Section 4.2 for sampling from metered data. That is, weights based on the number of meters per customer in each U-stratum, the utility's required response allocation, an allowance for listing error, and other parameters were used to select metered accounts from the listing for inclusion in the survey sample. More detailed information on the procedures used in Method 3 are presented in Appendix $A$ in the form of the worksheet that was used to implement Method 3 or Method 4 on all utilities that provided metered kWh consumption data to PNL.

After sampling was completed, listings of the selected meter accounts and the kWh consumption data were returned to the utilities with a request for the names, addresses, and telephone numbers (if available) corresponding to the selected accounts. In some cases, the utilities were asked to supply a specified number of names and addresses equal to $n_{u}$ (the number of customers to be included in the sample) chosen from among the selected metered accounts for each U-stratum. In other cases, the utilities provided names and addresses for all selected metered accounts and PNL staff checked for duplicates and reduced the number of customers for each strata to the desired number $\left(n_{u}\right)$.

\subsubsection{Method 4 - Sampling from a Metered List Not Sorted by kWh Usage}

This method was used when utilities kept their billing records in metered accounts, were unable to aggregate these metered accounts to an individual customer, and did not have the capability to readily provide a sorted meter Mh consumption listing. The results of using this method were similar to those of Method 3. However, more effort was required on the part of the PNL staff members who performed the sampling because of the difficulty associated with tallying metered accounts into their appropriate U-stratum from an unsorted listing. 


\subsubsection{Method 5 - Utility Sampling from Specified U-Strata}

Constraints related to aggregation of Mh consumption data and distribution of this data to PNL resulted in development of a sampling method which was implemented by the individual utility's staff. Five of the 40 utilities selected for the survey sample could not or would not provide PNL with a listing of customer or metered account data and it was not feasible for PNL personnel to visit the utility. Thus, it was necessary to use a sampling method that could select the most appropriate customers for the survey sample within the limits of these constraints.

In Method 5, the utility was provided with the representative U-strata cut points for customer or metered accounts within their G-stratum and instructed to select a specified number of customers from each U-stratum. Since PNL had no way of calculating a sampling interval based on how many accounts fell into a specific U-stratum, the utility was instructed to take a "geographically dispersed" sample. This helped to reduce the probability that the first accounts encountered were automatically selected.

Since PNL had no specific knowledge of the customer load Mh distribution, it was necessary to ask each of the six utilities which customers had the largest $\mathrm{kWh}$ consumption and an idea of the dispersion of remaining accounts. If the utility did not have the requested number of customers in a specified U-stratum, PNL staff reallocated the sample and requested more customer names and addresses from the smaller accounts. It should be noted that the five utilities from which customers were selected using Method 5 comprise a very small percentage ( 1.6 percent) of total regional irrigation load and of the irrigation survey sample.

\subsection{SAMPLING METHODS USED ON IRRIGATION SURVEY UTILITIES}

In this section, utilities have been grouped by the type of irrigation kwh consumption account listing they were able to provide. A distinction is made between:

- Customer consumption data provided by the utility (Methods 1 and 2).

- Metered consumption data provided by the utility (Methods 3 and 4). 
- The individual utility performed the sampling procedure according to specified U-strata provided by PNL (Method 5 ).

\subsubsection{Customer Consumption Data Provided by the Utility}

The utilities discussed in this section provided PNL with per-customer kWh consumption figures corresponding to individual irrigation customers. These utilities were sampled using either Method 1 or 2 and are listed in Table 5.1. They represent all geographic strata in the region and also comprised the majority (68 percent) of the tota? 1984 irrigation kWh load of all utilities selected for the sample. Although more effort was required of PNL staff to sample from an unordered listing using Method 2, the results were similar to those obtained from sampling from an ordered listing using Method 1.

For these utilities, an accurate identification of customers falling into the specific U-strata should have been obtained, since there were no multiple metered accounts to consider.

\subsubsection{Metered Consumption Data Provided by the Utility}

The utilities which did not have the capability to provide per-customer irrigation $\mathrm{kWh}$ consumption listing were asked to provide a listing of metered irrigation accounts. These utilities were sampled using either Method 3 or 4 and are listed in Table 5.2. The 9 utilities that provided metered data comprised approximately 30 percent of the total 1984 irrigation load of selected utilities. There will usually be a less accurate account of which U-stratum a customer belongs to using this data compared to individual customer consumption data.

\subsubsection{Utilities That Performed the Sampling Procedure According to Specified U-Strata (Method 5)}

In special cases where the utility was unable to provide PNL with an account/kWh consumption listing and it was not possible for PNL staff to visit the utility, the sampling procedure was performed by the utility. Five utilities fell into this category. They comprised about 2 percent of the total 1984 irrigation kWh for selected utilities. These utilities are listed in Table 5.3. As mentioned previously, this method posed the most difficult control problem because the sampling procedure was performed by the utility rather than PNL. 
TABLE 5.1. Utilities Providing Customer Irrigation Consumption Data (Method 1 or 2)

\begin{tabular}{|c|c|c|}
\hline $\begin{array}{l}\text { Geographical } \\
\text { Stratum } \\
\end{array}$ & Utility & $\begin{array}{c}1984 \text { Irrigation } \\
\text { MWh Usage } \\
\end{array}$ \\
\hline $0(1)^{(a)}$ & Idaho Power Company & $1,489,502$ \\
\hline 1 & $\begin{array}{l}\text { Fall River Rural Electric Cooperative } \\
\text { Raft River Rural Electric Cooperative }\end{array}$ & $\begin{array}{l}17,219 \\
94,253\end{array}$ \\
\hline 2 & $\begin{array}{l}\text { Columbia Rural Electric Association, Inc. } \\
\text { Franklin County PUD } \\
\text { Grant County Pun } \\
\text { Richland Energy Service, City of }\end{array}$ & $\begin{array}{r}107,400 \\
93,308 \\
321,985 \\
5,280\end{array}$ \\
\hline 3 & $\begin{array}{l}\text { Columbia Basin Cooperative } \\
\text { Umatilla Electric Cooperative Association } \\
\text { Wasco Electric Cooperative, Inc. } \\
\text { N. Wasco County PIID }\end{array}$ & $\begin{array}{r}30,748 \\
234,380 \\
8,832 \\
1,372\end{array}$ \\
\hline 4 & $\begin{array}{l}\text { Kittitas County PIID } \\
\text { Klickitat County PUD } \\
\text { Okanogan County PUD }\end{array}$ & $\begin{array}{r}2,935 \\
16,646 \\
43,786\end{array}$ \\
\hline 5 & $\begin{array}{l}\text { Central Electric Cooperative, Inc. } \\
\text { Columbia Power Cooperative } \\
\text { Surprise Valley Electrification Corporation }\end{array}$ & $\begin{array}{r}36,291 \\
4,264 \\
33,634\end{array}$ \\
\hline 5,5 & Harney Electric Cooperative & 58,697 \\
\hline 6 & Douglas County PUD & 30,182 \\
\hline 6,2 & Washington Water Power Company & 76,395 \\
\hline 7 & $\begin{array}{l}\text { Kootenai REA } \\
\text { Lost River Electric Cooperative, Inc. } \\
\text { Salmon River Electric Cooperative, Inc. } \\
\text { Vigilante Electric Cooperative, Inc. }\end{array}$ & $\begin{array}{r}6,425 \\
20,530 \\
8,020 \\
35,637\end{array}$ \\
\hline 8 & $\begin{array}{l}\text { Douglas Electric Cooperative } \\
\text { Portland General Electric }\end{array}$ & $\begin{array}{r}1,887 \\
38,000 \\
\end{array}$ \\
\hline & TOTAL & $2,817,608$ \\
\hline
\end{tabular}

(a) Idaho Power Company's irrigation load is primarily located in Geographic Stratum 1, but its relative irrigation load is so large that it was assigned its own stratum. In addition, the usage number shown is for the 1985 irrigation season, because this was the number used in defining the sampling method for this utility. 
TABLE 5.2. Utilities Providing Metered Irrigation

Consumption Data (Method 3 or 4)

\begin{tabular}{|c|c|c|}
\hline $\begin{array}{l}\text { Geographical } \\
\text { Stratum }\end{array}$ & Utility & $\begin{array}{l}1984 \text { Irrigation } \\
\text { Mwh Usage }\end{array}$ \\
\hline 1,7 & Utah Power and Light & 290,506 \\
\hline 2 & $\begin{array}{l}\text { Benton County PUD } \\
\text { Big Bend Electric Cooperative, Inc. }\end{array}$ & $\begin{array}{l}234,182 \\
216,041\end{array}$ \\
\hline $2,3,4,5,7,8$ & Pacific Power and Light company & 352,519 \\
\hline 4 & Chelan County PUD & 31,472 \\
\hline 4,2 & Renton Rural Electric Association & 58,874 \\
\hline 6 & Lincoln Electric Cooperative Incorporated (WA) & 54,492 \\
\hline 7 & $\begin{array}{l}\text { Ravalli County Electric Cooperative Incorporated } \\
\text { Washington Water Power Company }\end{array}$ & $\begin{array}{l}6,923 \\
6,939\end{array}$ \\
\hline 8 & Clallam County PuD & 1,363 \\
\hline & TOTAL & $1,253,311$ \\
\hline
\end{tabular}

TABLE 5.3. Utilities which Performed Sampling Procedures According to Specified U-Strata Provided by PNL

\begin{tabular}{llr}
$\begin{array}{c}\text { Geographical } \\
\text { Stratum }\end{array}$ & \multicolumn{1}{c}{ Utility } & $\begin{array}{c}\text { 1984 Irrigation } \\
\text { Mwh Usage }\end{array}$ \\
\cline { 1 - 1 } 1 & $\begin{array}{l}\text { East End Mutual Electric Company } \\
\text { South Side Electric Lines, Inc. }\end{array}$ & 4,093 \\
5 & Midstate Electric Cooperative, Inc., & 17,129 \\
6 & Inland Power and Light & 34,576 \\
7 & Flathead Irrigation and Power Project & 6,940 \\
& & TOTAL
\end{tabular}

5.3 RESPONSE ALLOCATION ADJUSTMENTS

It is statistically desirable to interview at least two customers from each Mwh usage stratum defined for each utility. Adjustments in the initial 
sample allocation for many of the utilities included in the sample were necessary in order to accomplish this objective. In some utilities, the number of customers in the high stratum were large enough that additional responses had to be added to the response allocation in order to obtain two responses in each stratum. For example, Raft River had 59 customers in the high stratum in 1934 , while its sample allocation was 51. In order to obtain all responses in the high stratum and two responses from each of the other stratum, it was necessary to raise Raft River's sample allocation to 69 .

The initial response allocations in some of the low group utilities were not large enough to obtain two responses in each stratum. Thus, wherever possible, the response allocations for these utilities were increased above their initial levels.

The final adjusted response allocations for the utilities in the survey sample are shown in Tables 5.4 and 5.5. The only exceptions to the practice of allocating two successful responses to each U-stratum in each utility occurred where two irrigation accounts did not exist in a specified U-stratum or the utility required that customer permission be obtained before it would release customer names.

Also shown in Tables 5.4 and 5.5 are the numbers of distinct customer names returned by the utilities from which the allocated number of responses are intended to be obtained for each utility. The difference between the number of allocated responses and the size of the sample list varies primarily because of three factors:

1. Utilities where a large number of irrigation customers are in the high stratum will have a small differential between allocated responses and sample list size because the goal is to survey all high stratum customers.

2. Utilities that required customer permission before releasing the names for the survey sample will normally have a lower total sample list size than their response allocation because such permission could not be obtained within the time frame of the study. 
TABLE 5.4. Final Allocated Successful Telephone Responses for High Group Primary Sampling Units in Irrigation Survey Sample

\begin{tabular}{|c|c|c|c|}
\hline G-stratum & utility & $\begin{array}{l}\text { Ad justed } \\
\text { Aliocotion }\end{array}$ & $\begin{array}{c}\text { Size of (a) } \\
\text { Sample } \\
\text { List }\end{array}$ \\
\hline 0 & Idaho Power Company & $200^{(b)}$ & 224 \\
\hline 1 & $\begin{array}{l}\text { Utah Pawer and LIght } \\
\text { Raft Rlver Cooperative }\end{array}$ & $139^{(c)}$ & $\begin{array}{r}250 \\
81\end{array}$ \\
\hline 2 & $\begin{array}{l}\text { Grant County PUD } \\
\text { Big Bend Electrlc }\end{array}$ & $\begin{array}{l}175 \\
117\end{array}$ & $\begin{array}{l}64^{(d)} \\
148\end{array}$ \\
\hline & $\begin{array}{l}\text { Benton County PUD } \\
\text { FrankI In County PUD } \\
\text { Columbia REA } \\
\text { Pacific Power and Llaht } \\
\text { Benton REA } \\
\text { Washington Water Power }\end{array}$ & $\begin{array}{r}127 \\
50 \\
58 \\
19 \\
12 \\
20\end{array}$ & $\begin{array}{r}154 \\
54 \\
71 \\
51 \\
26 \\
4\end{array}$ \\
\hline 3 & $\begin{array}{l}\text { Umatill la Electric Cooperative } \\
\text { Columbla Basin Electric } \\
\text { Poclific Power and Light }\end{array}$ & $\begin{array}{l}134^{(c)} \\
21 \\
46\end{array}$ & $\begin{array}{r}150 \\
21 \\
83\end{array}$ \\
\hline 4 & $\begin{array}{l}\text { Okanogan PUD } \\
\text { Pacific Power and Light } \\
\text { Benton REA } \\
\text { Chelan County PUD }\end{array}$ & $\begin{array}{l}23 \\
51 \\
25 \\
17\end{array}$ & $\begin{array}{r}27 \\
160 \\
37 \\
30\end{array}$ \\
\hline 5 & $\begin{array}{l}\text { Paclfic Power and Light } \\
\text { Surprise Valley Electric } \\
\text { Central Electric Cooperative } \\
\text { Mldstate Electrlc Cooperative } \\
\text { Harney Electric Cooperative (Nevada) }\end{array}$ & $\begin{array}{l}65 \\
20 \\
20 \\
16 \\
35\end{array}$ & $\begin{array}{l}138 \\
29 \\
25 \\
14 \\
40\end{array}$ \\
\hline 6 & $\begin{array}{l}\text { Lincoln Electrlc CooperatIve } \\
\text { Washington Water Power }\end{array}$ & $\begin{array}{l}34^{(c)} \\
22\end{array}$ & $25_{4}^{(d)}$ \\
\hline 7 & $\begin{array}{l}\text { Lost River Electric } \\
\text { Vigilante Electric }\end{array}$ & $\begin{array}{l}14 \\
22\end{array}$ & $\begin{array}{l}14 \\
30\end{array}$ \\
\hline 8 & $\begin{array}{l}\text { Paclitic Power and Light } \\
\text { Portland General Electric }\end{array}$ & $\begin{array}{l}12 \\
21 \\
\end{array}$ & $\begin{array}{l}42 \\
27 \\
\end{array}$ \\
\hline & TOTALS & 1584 & 2023 \\
\hline
\end{tabular}

(a) Number of distinct customer names returned by utillty.

(b) I daho Power Company was assigned a response all location of 200 because, based on the relative size of 1 ts irrigetion laod $(1.5$ million $\mathrm{M}$ (h) , over 500 of the 1700 total responses would have been all ocated to Idaho Power.

(c) Adjusted allocations for Utah Power and Light, Umatilla Electrlc Cooperative and Lincoln Electrlc Include allocotions for Low Group PSUs in alternative G-Strato 7,5 and 2 respectively.

(d) Customer permission requlred before names released. 
TABLE 5.5. Final Allocated Successful Telephone Responses for Low Group Primary Sampling Units in Irrigation Survey Sample

\begin{tabular}{|c|c|c|c|}
\hline G-Stratum & Selected Utility Name & $\begin{array}{l}\text { Adjusted Response } \\
\text { Allocation } \\
\end{array}$ & $\begin{array}{l}\text { Size of }(a) \\
\text { Sample List }\end{array}$ \\
\hline 1 & $\begin{array}{l}\text { Fall River } \\
\text { East End Mutual } \\
\text { South Side Electric }\end{array}$ & $\begin{array}{r}16 \\
6 \\
17\end{array}$ & $\begin{array}{r}24 \\
6 \\
26\end{array}$ \\
\hline 2 & Richland Energy Service & 6 & $6^{(b)}$ \\
\hline 3 & $\begin{array}{l}\text { Wasco Electric } \\
\text { North Wasco PUD }\end{array}$ & $\begin{array}{r}12 \\
7\end{array}$ & $\begin{array}{r}17 \\
7\end{array}$ \\
\hline 4 & $\begin{array}{l}\text { Klickitat PUD } \\
\text { Kittitas PUD }\end{array}$ & $\begin{array}{r}17 \\
9\end{array}$ & $\begin{array}{l}17 \\
12\end{array}$ \\
\hline 5 & $\begin{array}{l}\text { Marney Electric (Oregon) } \\
\text { Columbia Power Cooperative }\end{array}$ & $\begin{array}{r}16 \\
7\end{array}$ & $\begin{array}{l}17 \\
12\end{array}$ \\
\hline 6 & $\begin{array}{l}\text { Douglas County PUD } \\
\text { Intand Power and Light }\end{array}$ & $\begin{array}{r}19 \\
6\end{array}$ & ${ }_{9}^{32}(b)$ \\
\hline 7 & $\begin{array}{l}\text { Washington Water Power } \\
\text { Salmon River Cooperative } \\
\text { Flathead Power Project } \\
\text { Ravalli Electric } \\
\text { Kootenai REA } \\
\text { Pacific Power and Light }\end{array}$ & $\begin{array}{r}22 \\
11 \\
8 \\
12 \\
5 \\
10\end{array}$ & $\begin{array}{l}12^{(b)} \\
11 \\
11 \\
17 \\
5(b) \\
14\end{array}$ \\
\hline \multirow[t]{2}{*}{8} & $\begin{array}{l}\text { Douglas Electric Cooperative } \\
\text { Clallam County PUD }\end{array}$ & $\begin{array}{r}7 \\
12\end{array}$ & $\begin{array}{l}12 \\
23 \\
\end{array}$ \\
\hline & TOTALS & 225 & 290 \\
\hline
\end{tabular}

(a) Number of distinct cusomter names returned by utility.

(b) Customer permission required before names released.

3. Utilities where metered data was used as the basis for sample selection will generally have relatively large sample list sizes compared to their allocation due to use of the expansion weights based on the number of meters per customer (Table 4.3 ) in selecting the meter samples. 


\subsection{PROBLEMS OCCASIDNED BY SAMPLING BILLING RECORDS}

There are several problems that must be resolved in order to use the survey results to estimate population totals, percentages and other quantities of interest. The "population" of interest is irrigated farms in the BPA service area. However, a listing of irrigated farms from which to sample was not available. Instead, listings of billing records for the accounts classified as irrigation accounts by the utilities were used to define and select the sample. In addition to irrigated farms, these listings are likely to include accounts that are not "farms," for example, school districts, municipalities (for park watering or water treatment plants), and cemeteries.

The number of nonirrigated farms contained in the utilities' irrigation accounts will vary depending upon the various utilities' account classification methods and their customer characteristics. A preliminary analysis of the level of nonirrigated farms included in utilities irrigation billing records has already been conducted. In this analysis, the nonirrigated farm load was calculated as a percentage of the total irrigation load. The non-farm load included school districts, municipal water facilities, cemeteries and correctional facilities. The results of this analysis are shown in Table 5.6.

The results shown in Table 5.6 were developed using two types of data sources. When a listing of total irrigation account and kllh consumption was available, the MWh usage corresponding to the identified non-farm accounts was tabulated and the proportion of non-farm usage for the utility found. Since the entire population of accounts was evaluated, the most accurate measure of non-farm usage was possible. The six utilities evaluated in this manner are marked with an A in Table 5.5.

In other cases, only the names and addresses selected according to the stratified random sampling methods described in this report were available. The non-farm accounts were identified and, since we had no specific consumption figure, assigned the MWh consumption for the midpoint of the usage strata in order to estimate the proportion of non-farm usage for the utility. The utilities analyzed using this method are marked with a $B$ in Table 5.6. 
TABLE 5.6. Sample Data on Nonirrigated Farm Loads Contained in Irrigation Billing Records

\begin{tabular}{|c|c|c|c|c|c|}
\hline Stratum & $\begin{array}{c}\text { Data } \\
\text { Used } \\
\end{array}$ & Utility Sampled & $\begin{array}{l}1984 \\
\text { Irrigation } \\
\text { Load (MWh) }\end{array}$ & $\begin{array}{l}\text { Nonirrigated } \\
\text { Farm Logd } \\
\text { (MWh) }\end{array}$ & $\begin{array}{l}\text { Nonirrigated } \\
\text { Farm Load }(\%)\end{array}$ \\
\hline 1 & $\begin{array}{l}B \\
A\end{array}$ & $\begin{array}{l}\text { Raft River } \\
\text { South Side }\end{array}$ & $\begin{array}{l}94,253 \\
17,129\end{array}$ & $\begin{array}{l}0 \\
0\end{array}$ & $\begin{array}{l}0 \\
0\end{array}$ \\
\hline 2 & $\begin{array}{l}B \\
B \\
B\end{array}$ & $\begin{array}{l}\text { Benton County } \\
\text { Franklin County } \\
\text { PP\&L }\end{array}$ & $\begin{array}{r}234,182 \\
93,308 \\
30,683\end{array}$ & $\begin{array}{c}150^{(c)} \\
0 \\
135^{(c)}\end{array}$ & $\begin{array}{l}0.06 \\
0 \\
0.44\end{array}$ \\
\hline 3 & $\begin{array}{l}\text { B } \\
B \\
B \\
A \\
B\end{array}$ & $\begin{array}{l}\text { Columbia Basin } \\
\text { North Wasco } \\
\text { Wasco Electric } \\
\text { Umatilla } \\
\text { PP\&L }\end{array}$ & $\begin{array}{r}30,748 \\
1,372 \\
8,832 \\
234,380 \\
84,118\end{array}$ & $\begin{array}{r}0 \\
0 \\
0 \\
51 \\
0\end{array}$ & $\begin{array}{l}0 \\
0 \\
0 \\
0.02 \\
0\end{array}$ \\
\hline 4 & $\begin{array}{l}A \\
B\end{array}$ & $\begin{array}{l}\text { Klickitat } \\
\text { PP\&L }\end{array}$ & $\begin{array}{l}16,646 \\
97,182\end{array}$ & $\begin{array}{r}151 \\
0\end{array}$ & $\begin{array}{l}0.90 \\
0\end{array}$ \\
\hline 5 & $\begin{array}{l}B \\
B \\
B \\
B\end{array}$ & $\begin{array}{l}\text { Central Electric } \\
\text { Surprise Valley } \\
\text { PP\&L } \\
\text { Harney Electric }\end{array}$ & $\begin{array}{r}36,291 \\
40,941 \\
118,234 \\
58,274\end{array}$ & $\begin{array}{l}0 \\
0 \\
0 \\
0\end{array}$ & $\begin{array}{l}0 \\
0 \\
0 \\
0\end{array}$ \\
\hline 6 & B & Douglas PUD & 30,182 & $15^{(c)}$ & 0.05 \\
\hline 7 & $\begin{array}{l}\mathrm{B} \\
\mathrm{A} \\
\mathrm{A} \\
\mathrm{A}\end{array}$ & $\begin{array}{l}\text { PP\&L } \\
\text { Vigilante } \\
\text { Salmon River } \\
\text { Lost River }\end{array}$ & $\begin{array}{r}1,368 \\
35,637 \\
8,020 \\
20,530\end{array}$ & $\begin{array}{l}32.1^{(c)} \\
33 \\
54 \\
17\end{array}$ & $\begin{array}{l}2.35 \\
0.09 \\
0.67 \\
0.08\end{array}$ \\
\hline 8 & $\begin{array}{l}\mathrm{B} \\
\mathrm{B}\end{array}$ & $\begin{array}{l}\text { PGE } \\
\text { PP\&L }\end{array}$ & $\begin{array}{l}37,000 \\
20,934\end{array}$ & $\begin{array}{c}30^{(c)} \\
0\end{array}$ & $\begin{array}{l}0.08 \\
0\end{array}$ \\
\hline 0 & B & $\begin{array}{l}\text { Idaho Power } \\
\text { TOTALS }\end{array}$ & $\frac{1,489,502}{2,839,746}$ & $\frac{2,000}{2,668.1}$ & $\frac{0.13}{0.09}$ \\
\hline
\end{tabular}

(a) $A=1984$ "irrigation" kWh listing provided by the utility; $B=$ sample of "irrigation" accounts selected for the utility using the stratified random sampling methods described in this report.

(b) Sum of loads identified in irrigation billing records as school districts, municipal water facilities, cemetaries and correctional facilities.

(c) Derived using the average Mh usage for the strata. 
Note from Table 5.6 that, for the utilities analyzed, nonirrigated farm accounts (as defined by school districts, municipal water plants, cemeteries and correctional centers) are generally less than 1 percent of the selected utilities irrigation load. Thus, the results of this preliminary analysis indicate that the problem of nonirrigated farms being included in billed irrigation demand may not be large for most utilities.

In addition to those accounts that obviously do not represent irrigated farms (such as those upon which Table 5.6 is based), there are a number of accounts designated as "irrigation districts" in the billing records that represent a grey area as to whether they represent irrigated farms or not. In some cases, a farmer or group of farmers may form an irrigation district that does represent a farm where electricity is being used to deliver water directly to croplands. In other cases, irrigation districts only use electricity to distribute water within surface water delivery systems (canals, ditches, etc.) and do not represent irrigated farms. The problems associated with the eligibility of irrigation districts and other nonfarm "irrigators" will likely be dealt with through the use of an operational definition of "irrigated farm" and subsequent classification of some sampled accounts as "ineligible." Then the "case weights" for estimating population totals would be based on the eligible population and Mh used by it, similar to the method used in other studies (Lou Harris and Associates, 1984 and WESTAT 1982). Some screening of "ineligibles" was done for the sample listing and at the start of the telephone interviews.

Other problems that were associated with the required use of billing record data for developing a sample for the irrigation survey include:

- the need to use metered load data that could not aggregate MWh consumption to an individual customer in selecting a sample for some utilities

- a requirement by seven utilities that customers' permission be received either through a signed consent form or a telephone call before the customers' names could be released for inclusion in the survey sample. 
The goal of the study is to sample irrigated farms, but the probability o* selecting a farm from a meter listing is not known unless we know how many meters are billed to the farm. If a utility provided us with a meter listing that had customers identified by a customer account number, we aggregated the billed meters to a customer total and sampled customers.

The multiple listing problem arising from the use of metered accounts can be resolved by calculating inclusion probabilities similar to the handing of multiple meter problems in other studies (WESTAT 1982). However, for the utilities that provided only meter data, we will have to await the survey results to determine appropriate case weights for estimation purposes.

The seven utilities which required that customers' permission be received (either through a signed consent form or a telephone call) before the cus tomers' names could be released for inclusion in the survey sample represented approximately 12 percent of 1984 regional irrigation load. These utilities are listed in Table 5.7. Also shown in Table 5.7 are the utilities initial response allocations and the number of customers whose names were actually released.

TABLE 5.7. Initial Response Allocations for Utilities Requiring Customer Permission for Name Release and Names Actually Received

\begin{tabular}{lccc}
$\begin{array}{c}\text { Utility Requiring } \\
\text { Permission }\end{array}$ & $\begin{array}{c}\text { Initial Response } \\
\text { Allocation }\end{array}$ & $\begin{array}{c}\text { Customer Names } \\
\text { Actually Received }\end{array}$ \\
\cline { 1 - 2 } Grant County PuD & 175 & 64 \\
Washington Water Power & 64 & 22 \\
Lincoln Electric Cooperative & 34 & 24 \\
Midstate Electric Cooperative & 16 & 14 \\
Inland Power and Light & 4 & 9 \\
Kootenai REA $\quad 6$ & 6 & 5 \\
Richland Energy Services & 6 & 6 \\
&
\end{tabular}


permission was not received from the customers within a month. The utilities conducted these activities to the degree that their staff resources would allow. However, in most cases, it was not feasible for the utilities to attempt to contact every customer who did not return a permission form. The process of collecting waivers was conducted for approximately two months and was discontinued only when the time constraints of conducting the survey required that it be stopped.

It is obvious from Table 5.7 that the listed utilities will not be as well represented in the results of the irrigation survey as they would have been if their desired sample allocations had been reached. This is particularly true for Washington Water Power and Grant County PUD. Appropriate statistical adjustments for responses obtained from the customers of these utilities will be particularly necessary when the survey results are received.

\subsection{SIMMARY OF SAMPLING METHODOLOGY}

Despite the problems introduced by sampling from billing records, the sample produced by the methods described in this report will lead to a significant improvement in the precision of estimation compared to a simple random sample. Sampling decisions were based on what theory indicated would produce good precision in estimating MWh load, irrigated acres and other parameters of interest. These decisions included:

- selecting high-usage utilities with certainty

- selecting high-usage customers with certainty

- selecting low-usage utilities with probability proportional to size

- randomly selecting low-usage customers within "strongly stratified" usage strata.

The resulting sample will provide the theoretically best precision for those survey items that are well-correlated with usage when ratio or other regression-based estimates are used, given the fixed sample size we allocated to the utilities. 
The improvement in precision that will be obtained from using the sampling plan described in this report as opposed to other plans can be illustrated through the use of an example for a selected utility. For purposes of illustration, Grant County PUD was selected for analysis, although the principles $0^{*}$ the example are applicable to any of the utilities for which customer Mh consumption data were available for sampling.

Grant County PUn delivered 321,985 MWh to 2148 customers in 1984 . It was allocated a completed response $\left(n_{r}\right)$ of 175 . It was found that 120 customers used more than $500 \mathrm{MWh}$, leaving 2028 customers from which to draw a sample and obtain 55 responses from the sample. In order to compare sampling plans, the plans are evaluated in reference to their precision in estimating the total Mwh billed in 1984. Since we know the Mwh for each customer such evaluation is possible.

If a simple random sample of 175 customers were drawn from the 2148 customers, then the standard deviation for an estimate of total Mwh would be

$$
\text { sd }(T \text { MWh })=60,911 \mathrm{MWh}
$$

which is 18.9 percent of the total 1984 MWh of 321,985 . If we selected the 120 high-usage customers with probability one and used simple random sampling for drawing 55 from the remaining 2028 , then

$$
\text { sd }(T \text { Mh })=25,750 \text { Mwh }
$$

which is 8 percent of total $1984 \mathrm{MWh}$. For the sampling plan described in this report, which involves selecting the high-usage customers with probability one and randomly selecting the same number of customers from each low-usage stratum, the standard deviation is

$$
\text { sd }(T \text { MWh })=8,530.96
$$

or 
These figures show a marked improvement; the standard deviation of estimates (the statistical measure of precision) improves from 18.9 percent of the total to be estimated using a purely random sample to 2.54 percent for the sampling plan described in this report. These results are for simple inverse probability of selection estimators for variables that have distributions similar to MWh. Even better precision can be expected when ratio estimates, using MWh, are made for variables that are correlated with MWh. 

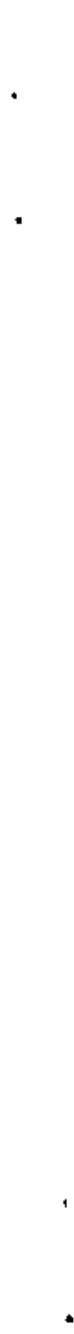
Harrer, B. J., A. J. Lezberg, and G. L. Wilfert, 1985. An Integrated Assessment of Conservation Opportunities in the Irrigated Agriculture Sector of the Pacific Northwest Region. PNL-5406, Pacific Northwest Laboratory, Richland, Washington.

Lou Harris and Associates, Inc. 1984. Pacific Northwest Residential Energy Consumption Survey: Construction of Mutticomponent Case Weights for Regional Sample Data Final Report. Study No. 833004 .

WESTAT. 1982. Nonresidential/Commercial Buildings Energy Consumption Feasibility Study. Volume I. Final Report. Contract No. EI-78-C-01-6367, WESTAT, Rockville, Maryland.

Wright, R. L. 1982. "Electric Utility Load Research Using Model-Based Statistical Sampling." Presented in Proceedings of the 1981 DoE Statistical Symposium. BNL-51535, Brookhaven National Laboratory, Jpton, Long Island, New York. 


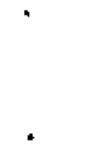

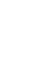




\section{APPENDIX A}

SAMPLING WORK SHEETS 
TABLE A.1. Worksheet for Sampling From Customer kwh Load Data Using Sampling Method 1 or 2

Given: 1. Utility irrigation customer kWh consumption listing

2. Upper limits for the low MWh usage stratum for the geographical Stratum the utility is in

3. The allocated sample size, $n_{r}$

Step 1. List all customers using at least $500,000 \mathrm{kwh}$ in Sample Listing.

Step 2. Count customers listed in Step 1 , getting $n_{H}$, and calculate as follows:

$$
\begin{aligned}
& n_{r}=\ldots \text { sample size } \\
& \mathrm{n}_{\mathrm{H}}=\ldots \text { number of customers using at } \\
& \text { least } 500 \text { MWh } \\
& n_{L}=n_{r}-n_{H}= \\
& n_{L S}=\left[1.333 n_{L}\right]_{I}+1=\ldots \begin{array}{l}
\text { approximate number to sample in } \\
\text { low group }
\end{array} \\
& n_{L}^{\prime}=n_{L S}+c_{5}=\ldots \begin{array}{c}
\text { number to sample in low-usage } \\
\text { group }
\end{array} \\
& n_{U}=N_{L}^{\prime} / 5= \\
& n_{r u}=\left(n_{L}+c_{5}^{\prime}\right) / 5= \\
& \text { number of respondents for low } \\
& \text { group } \\
& \text { number to sample in each of the } \\
& \text { five low-usage strata } \\
& \text { number of respondents in each } \\
& \text { low-usage stratum. }
\end{aligned}
$$

Notes:

$[\cdot]_{I}$ means truncate to the inter part. $c_{5}$ and $c_{5}^{\prime}$ are integers, $(0,1,2$, 3 , or 4) that make $n_{L}$ or $n_{r u}$ exactly divisible by 5 . 
TABLE A.1. (contd)

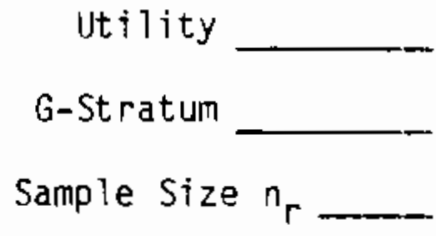

SUMMARY TABLE FOR CUSTOMER LOAD DATA

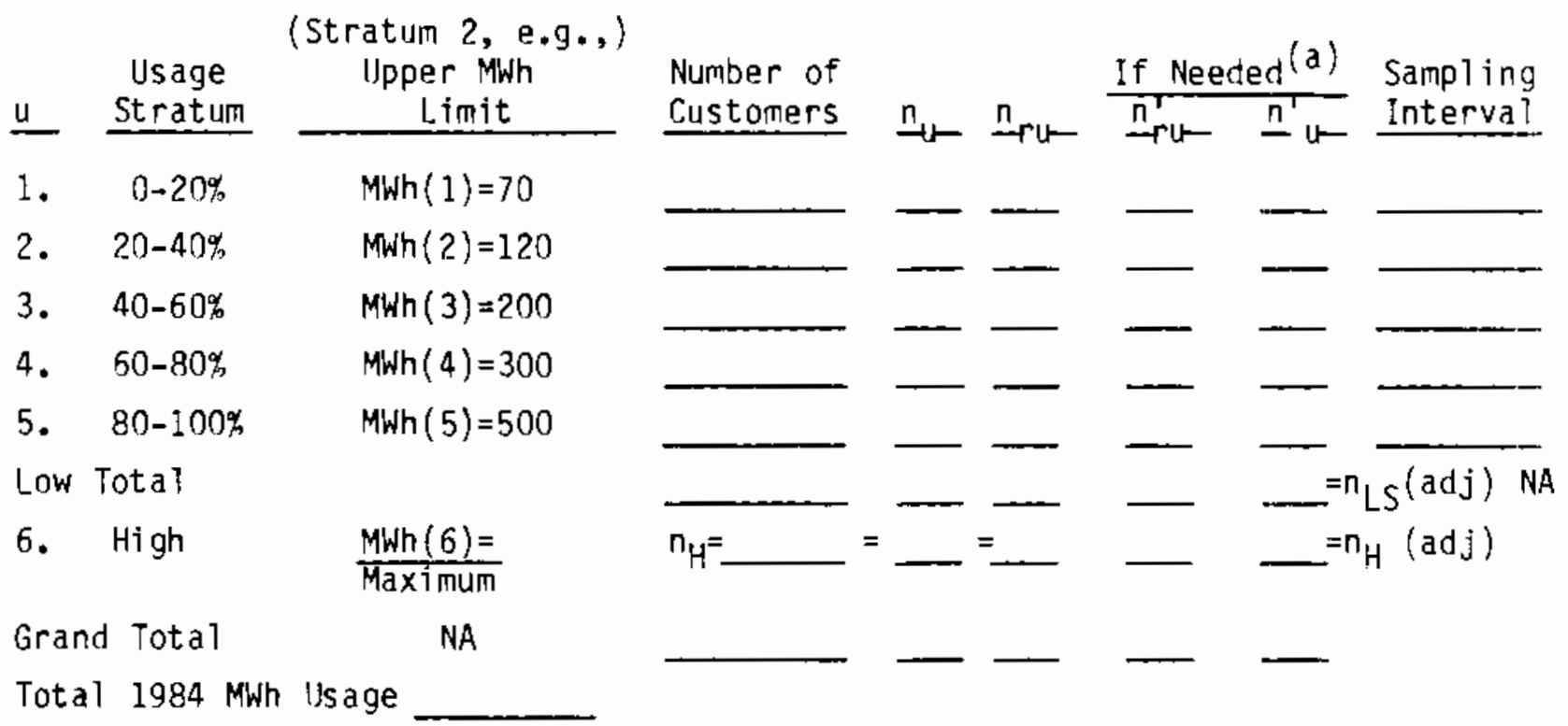

(a) These columns are needed if $n_{u}$ is greater than the number of customers for any usage strata. (See Table 4.2 for an example.) Then

$$
n_{L}(\operatorname{Adj})=n_{r}-n_{H}-\operatorname{NCIUST}(5)-\operatorname{NCUST}(4)-\ldots \text { - NCUST (HI) }
$$

where the adjustment to $n_{L}$ is to subtract off NCUST for each usage stratum that has $n_{u}$ greater than NCUST and NCUST (HI) is the last such stratum

$$
\begin{aligned}
& n_{H}(\text { Adj })=n_{H}+\operatorname{NCUST}(5)+\ldots+\text { NCIST }(H I) \\
& n_{L S}(\text { Adj })=\left[1.333 n_{L}(\text { Adj }]+1\right. \\
& n_{u}^{\prime}=\left(n_{L S}+c_{5}\right) / S \text {, where } S \text { is the number of low-usage strata with } \\
& \quad n_{U} \text { less than NCUST. } \\
& n_{r u}^{\prime}=\left[n_{r}-n_{H}(\text { Adj })+c_{5}\right] / 5 .
\end{aligned}
$$


TABLE A.2. Worksheet for Sampling From Meter kWh Load Data Using Sampling Method 3 or 4

Given: Listing of meter consumption. U-ST M:h limits for G-ST. $\mathrm{n}_{r}$ Step 1. Count NMET in each U-ST.

Step 2. Let $M_{H}$ be the number of meters in U-ST6.

Step 3. Calculate the expected number of customers in U-ST6 as

$$
n_{H}=\left[M_{H}(0.3846)\right]_{I}+1 \quad \frac{\text { e.g., for } n_{r}=17, M_{H}=5}{[5(0.3846)]_{I}+1=2}
$$

and

$$
\begin{array}{rlrl}
n_{L} & =n_{r}-n_{H} & & 17-2=15 \\
n_{L S} & =\left[1.333 n_{L}\right]_{I}+1 & & {[1.333(15)]_{I}+1=20} \\
n_{L}^{\prime}=n_{L S}+c_{5} & 20+0=20 \\
n_{U}=n_{L}^{\prime} / 5 & 20 / 5=4
\end{array}
$$

also

$$
n_{u r}=\left[n_{L}+c_{5}^{\prime}\right]_{I} \quad 15 / 5=3
$$

Step 4. Calculate the number of meters to sample for U-ST 1-5 as

$$
\begin{aligned}
& \text { e.g. } \\
& \begin{array}{lllll}
1 & 2 & 3 & 4 & 5
\end{array} \\
& M_{u}=\left[\begin{array}{ll}
E_{U} & n_{u}
\end{array}\right]_{I}+1 \\
& \begin{array}{llllll}
E_{u} & 1.3 & 2.0 & 2.5 & 3.5 & 4.3
\end{array} \\
& \begin{array}{llllll}
M_{U} & 5 & 8 & 10 & 14 & 17
\end{array} \\
& I_{u}=\left[\operatorname{NMET}_{u} / M_{u}\right]_{I}
\end{aligned}
$$

Step 5. Space to do these calculations is provided at the bottom of Summary Table for Meter Data. Enter the results on the appropriate lines in the table. 
TABLE A.2. (contd)

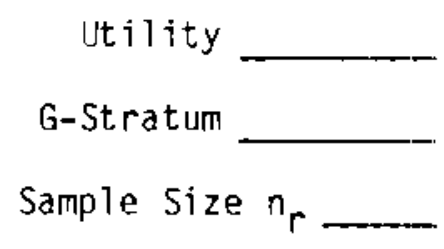

SUMMARY TABLE FOR METER LOAD DATA

Mwh

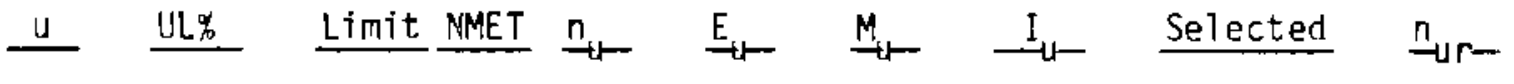

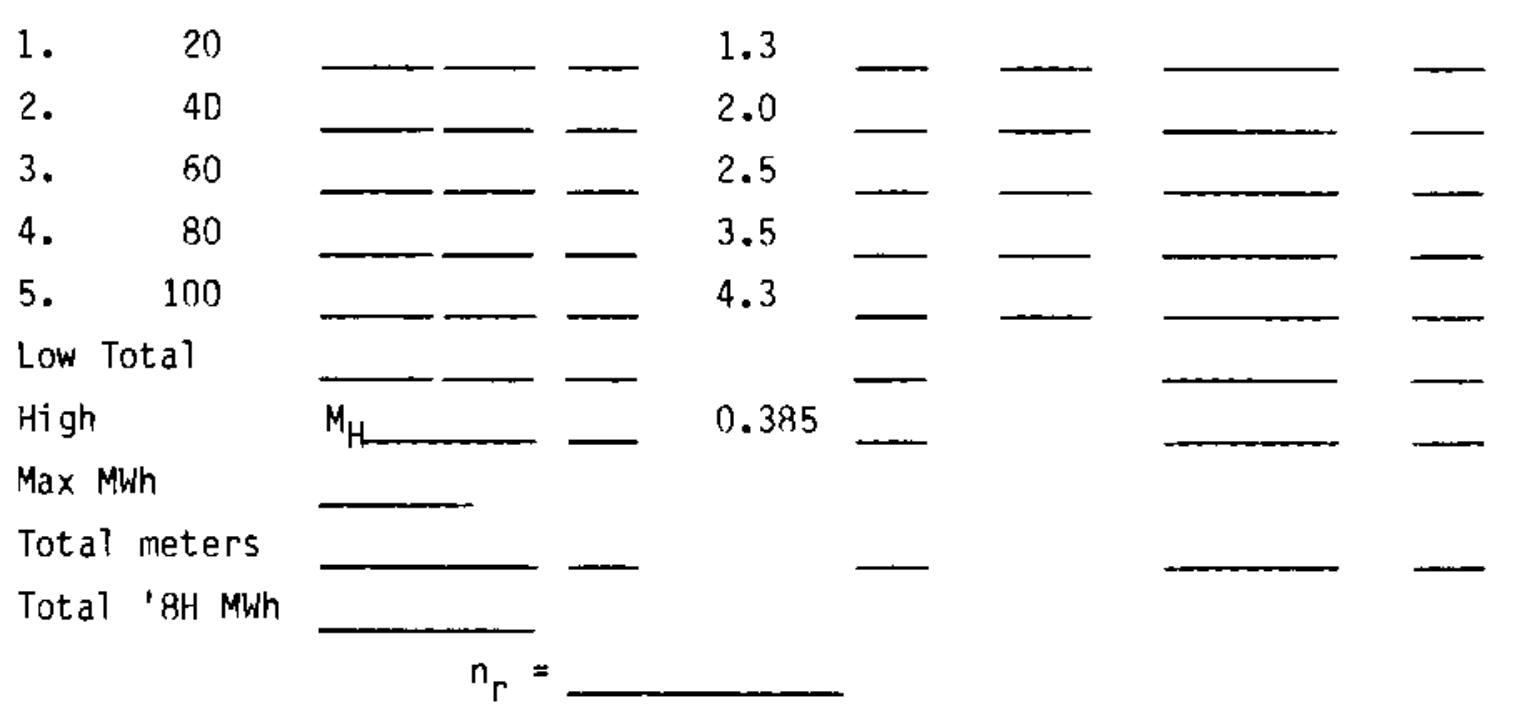

$$
\begin{array}{r}
n_{H}=\left[M_{H}(0.3846)_{I}+1=\right. \\
n_{L}=n_{r}-n_{H}= \\
n_{L S}=\left[1.333 n_{L}\right]_{I}+1= \\
n_{L}^{\prime}=n_{L S}+c_{5}= \\
n_{U}=n_{L}^{\prime} / 5= \\
n_{u r}=\left[\left(n_{L}+c_{5}^{\prime}\right) / 5\right]_{I}= \\
M_{U}=\left[E_{U^{n}} n_{U}\right]_{I}+1 \\
I_{U}=\operatorname{NMET}_{U^{\prime}} / M_{U}
\end{array}
$$


APPENDIX B

ALPHABETICAL LISTING OF UTILITIES INCLUDED IN SAMPLE 


\begin{tabular}{|c|c|c|c|}
\hline utility & $U 10^{(8)}$ & $\begin{array}{l}1984^{(b)} \\
\text { MWH SUM } \\
\end{array}$ & PSUs \\
\hline Benton PUD & 24 & 234,182 & 1 \\
\hline Benton REA & 27 & 58,874 & 2 \\
\hline Big Bend Elec. Coop. & 30 & 216,041 & 1 \\
\hline Central Elec, Coop. & 64 & $36,29 i$ & $i$ \\
\hline Chelan Co. PUD & 79 & 31,472 & 1 \\
\hline $\mathrm{Clallam}$ PUD & 98 & 1,363 & 1 \\
\hline Columbia Basin Coop. & 110 & 30,748 & 1 \\
\hline Col umbla REA & 113 & 107,400 & 1 \\
\hline Columbia Pover Coop. & 116 & 4,264 & 1 \\
\hline Douglas PUD & 140 & 30,182 & 1 \\
\hline Douglas Elec. Coop. & 143 & 1,887 & 1 \\
\hline East End Mutual & 152 & 4,093 & 1 \\
\hline Foll River COOD. & 170 & 17,219 & 1 \\
\hline Frankiln PUD & $19 !$ & 93,308 & 1 \\
\hline Grant PuD & 197 & 321,985 & 1 \\
\hline Harney Coop. & 203 & $5 B, 697$ & 2 \\
\hline Idaho Power Co. & 215 & $1,489,502$ & 1 \\
\hline Inland P\&L & 221 & 6,940 & 1 \\
\hline KIttitas PUD & 224 & 2,935 & 1 \\
\hline KIlckitat PUD & 227 & 16,646 & 1 \\
\hline Kootenal REA & 230 & 6,425 & 1 \\
\hline Llncoln Coop. (WA) & 243 & 54,492 & 1 \\
\hline Lost River Coop. & 246 & 20,530 & 1 \\
\hline Midstate Coop. & 262 & 34,576 & 1 \\
\hline N. Wasco PUD & 295 & 1,372 & 1 \\
\hline Okanogan PUD & 304 & 43,786 & $i$ \\
\hline Pacific P\&L & 326 & 352,519 & 6 \\
\hline Portland Gen'I Elec. & 353 & 38,000 & 1 \\
\hline Raft River Coop. & 366 & 94,253 & 1 \\
\hline Ravalli Coop. & 369 & 6,923 & 1 \\
\hline Richland City LIght & 372 & 5,280 & 1 \\
\hline Salmon RIver Coop. & 390 & 8,020 & 1 \\
\hline South Side Elec. Lines & 409 & 17,129 & 1 \\
\hline Surpelse Valley Coop. & 424 & 33,634 & 1 \\
\hline UmetIIla Elec, Coop & 439 & 234,380 & 1 \\
\hline USI is-Fiathead & 451 & 22,885 & 1 \\
\hline Utah P\&L & 457 & 290,506 & 1 \\
\hline Vigilante Elec. Coop. & 459 & 35,637 & 1 \\
\hline Wasco Elec, Coop. & 467 & 8,832 & 1 \\
\hline washington water Power & 470 & 83,334 & 3 \\
\hline Total for 40 utilities & & $4,156,542$ & 49 \\
\hline
\end{tabular}

(a) Utillty Identification Number from BPA Historlcal Sales Data Files.

(b) 1984 Data except for Idaho Power Co. (1985 data), clallam PJD and 25,000 Mwh for WhP (1980 data). 
PNL-5866

UC $-95 \mathrm{C}$

\section{DISTRIBUTION}

No. of

Copies

OFFSITE

2 Eric Westman

Bonneville Power Administration

P.0. Box 3621

Portland, Oregon 97208

Curt Hickman

Bonneville Power Adminstration

P.0. Box 3621

Portland, Oregon 97208

Fred Gordon

Bonneville Power Administration

P.0. Box 3621

Portland, Oregon 97208

30 DOE Technical Information Center

Mary Corrigan

Department of Energy

Forrestal Building

Washington, D.C. 20585
No. of

Copjes

ONSITE

DOE Richland Operations office

J. J. Sutey

17 Pacific Northwest Laboratory

B. L. Mohler

A. J. Lyke

L. J. Davis

G. L. Wilfert

J. W. Johnston

B. J. Harrer (4)

G. M. Stokes

Publishing Coordination (2)

Technical Information (5) 


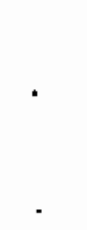

, 